The Journal of Agriculture of the University of Preprto Rico In continuation of The Journal of the Department of Agriculture of Puerto Rico

Published Quarterly; January, April, July and Octaber of each year

MELVILLE T. COOK. EDITOR

\begin{tabular}{llll}
\hline Vol. XX & October 1936 & No. 4 \\
\hline
\end{tabular}

\title{
THE ANTS OF PUERTO RICO
}

\author{
By M. R. SмITH,
}

Bureau of Entomology and Plant Quarantine, United States Department of Agriculture.

For approximately one year, from July 1935 to early June 1936, the writer was stationed in Puerto Rico in connection with investigations of insect pests of Puerto Rico conducted with special funds available to the Bureau of Entomology and Plant Quarantine. His particular assignment was to investigate insects attacking coffee, especially with reference to the relationship between ants and certain mealybugs and scale insects attacking coffee. In connection with the ant phase of the coffee insect problem in Puerto Rico, opportunity was given for travel over the island and, incidental to these investigations relating to coffee insects, the writer made a rather extensive collection of the ants that are found in Puerto Rico and observations concerning their occurrence. The first series of specimens of each species is deposited in the collection of the U. S. National Museum, and duplicates will be deposited in other collections.

Very little was known about the ant fauna of Puerto Rico until March 1908. During that month, Dr. W. M. Wheeler of Harvard University visited the island and made a collection and study of the ants. Although collections were made on the main island and several of the smaller, adjacent islands, no visits were made to Vieques or to the rich tropical forest of the highest mountain on the island, El Yunque. The thoroughness of Wheeler's work and the accuracy of his observations are more apparent perhaps to one like myself who has attempted to study the ants in the same localities studied by Wheeler 28 years ago. My collections and studies for the most part have been made on the western end of the island, principally in the región centering around Mayagüez where the rainfall is ap- 
proximately 80 to 100 inches each year and altitudes range from sea level to about 3,000 feet (one of the peaks in the Maricao Insular Forest). I did not visit any of the smaller islands nor have I collected on El Yunque. At first thought it might appear foolish for one to collect and study ants in a region that has already been rather adequately covered. However, I spent one year on the island, whereas Wheeler had only a few weeks in which to make his observations. As a result of my longer stay on the island I was able to collect more information on the distribution, biology, and economic importance of the ants than was permitted Wheeler.

As Wheeler has previously and aptly stated, one would not expect to find as many ants on an island as on a continental area of similar size; furthermore, with an island so densely populated as Puerto Rico (465 inhabitants to the square mile) and practically all of the land in cultivation, few areas of virgin forest are left and these only on the highest mountains. My collecting in the Maricao Insular Forest, however, around altitudes of 3,000 feet has been rather disappointing. Here I found only about ten species and these included only one new form although I have searched this area for ants at least a half dozen times.

The ants that are most apt to attract the casual observer's attention in Puerto Rico are such species as the "hormiga brava", Solenopsis geminata Fabr.; the "hormiga loca", Prenolepis longicornis Latr.; the "albaricoque", Tapinoma melanocephalum Fabr.; and Pheidole fallax jelskii var. antillensis Forel. The habits of these ants are discussed rather fully elsewhere in this article, so the species need not be considered further here.

In 1908 Wheeler listed 51 species of ants for the island, if we omit Neoponera villosa Fabr., which I feel quite positive does not occur in Puerto Rico. Wolcott, in listing the ants of the Island in his Insectae Portoricensis (1923), records 55 species. I have failed, however, to include in this article 3 of the species mentioned by Wolcott, namely, Pseudomyrma flavidula var. delicatula Forel, Monomorium minutum Mayr, and Camponotus cuneiscapus Emery, there being some doubt in my mind that two of these species, at least, occur in Puerto Rico. Even with these exceptions the article includes 66 species. Of 
this number 20 species (or 30.3 percent) have been described from Puerto Rico. The species referred to are as follows:

1. Cerapachys (S.) seini Mann

2. Odontomachus haematoda var. notata Mann

3. Cardiocondyla venustula Whlr.

4. Solenopsis globularia var. borinquenensis Whlr.

5. Solenopsis globularia var. desecheoensis Mann

6. Solenopsis azteca var. pallida Whlr.

7. Pheidole subarmata var. borinquenensis Whlr.

8. Pheidole moerens Whlr.

9. Macromischa isabellae Whlr.

10. Macromischa isabellae mutica subsp. nov.

11. Macromischa albispina Whlr.

12. Macromischa albispina subsp. pailipes Mann

13. Strumigenys louisianae var. obscuriventris Whlr.

14. Myrmicocrypta brittoni Whlr.

15. Mycocepurus smithi var, borinquenensis Whlx.

16. Iridomyrmex melleus Whir.

17. Iridomyrmex melleus var. fuscescens Whlr.

19. Myrmelachista ramulorum Whlr.

19. Myrmelachista ramulorum subsp. fortior Whlr.

20. Prenolepis (Nylanderia) microps sp. nov.

Eight species (or 12.1 percent) are introduced forms. These are:

1. Monomorium pharaonis Linn. "Pharaoh's ant"

2. Monomorium destructor Jerdon

3. Monomorium floricolw Jerdon

4. Pheidole megacephala Fabr.

5. Tetramorium guineense Fabr.

6. Tetramorium simillimum Nyl.

7. Prenolepis (Nylanderia) longicornis Lat:., "crazy . ant"

8. Tapinoma melanocephalum Fabr., "albaricoque"

The rarest ant that has been found on the Island is Cerapachys seini, a species representing one of the most primitive of the subfamilies of ants and not known from any other island of the West Indies than Puerto Rico. The absence of any of the 
species of the subfamily Dorylinae is also worth remarking about. These ants are apparently very rare in the West Indies, having been collected to date only from the Islands nearest South America, namely, St. Vincent, Grenada, and Trinidad. A number of genera in Puerto Rico have only one or so species in them, such genera being Crematogaster, Pseudomyrma, Camponotus, Tapinoma, Iridomyrmex, etc. Some of the tropical genera like Cryptocerus, Dolichoderus, Azteca, and Eciton are devoid of any representatives at all.

In preparing this article I have drawn freely on Wheeler's bulletin, "The Ants of Puerto Rico and the Virgin Islands", and the list of ants in Wolcott's "Insectae Portoricensis". In addition to this, various colleagues have very kindly turned over to me their records which pertain to the distribution or habits of the ants as well as their associations wth other economic insects. To conserve space in the following article the names of these are given by initials. The men referred to are as follows: George N. Wolcott, Francisco Sein, Jr., W. M. Wheeler, W. M. Mann, F. E. Lutz, D. L. Van Dine, H. L. Dozier, A. H. Madden, J. W. Balock, T. H. Jones, F. M. Wadley, L. C. Fife, J. D. Moore, R. H. Van Zwaluwenberg, H. K. Plank, José Sepulveda, and the writer.

\section{KEY TO THE SUBFAMILIES (for the identification of workers)}

1. Cloacal orifice round, terminal, surrounded by a fringe of hairs Formicinae Cloacal orifice ventral, slit-shaped

2. Petiole 1 - segmented

Petiole 2-segmented

3. No definite constriction between the first and second gastric segments; body soft and flexible; anal glands present which often produce a very characteristic odor

Dolichoderinae

A definite constriction between the first and second gastric segments; body wall firm_-__Ponerinae and Cerapachyinae

4. Clypeus not prolonged back between the frontal carinae; median spurs of middle and hind legs pectinate; erres excessively large; elongate, rather slender ants _._._._._._._._._._. Pseudomyrminae Clypeus almosi always prolonged back between the frontal carinae, if not, then the spurs of the middle and hind tibiae are simple or absent...Myrmicinae 


\section{SUBFAMILY CERAPACHYINAE}

\section{Cerapachys $(S)$ seini Mann}

Jour. Wash. Acad. Sci., Vol. 21, pp. 440-441, 1931. Worker Río Piedras (F. S.)

This rare ant was found by Francisco Sein in a sugar cane field at Rio Piedras, where Mr. Sein observed the larvae of the ant feeding on the larva of the sugar cane root caterpillar, Perforadix sacchari Sein. No other species of this rare genus has been found in any of the West Indian Islands, which thus makes the record a very unique one. It is presumed that this ant may have been imported into Puerto Rico through sugar cane introductions.

The worker of this species can be partly distinguished by its 9-segmented antenna and the lateral carina on each side which separates it from the cheek. The antennal insertions are exposed, and the frontal carine are distinct from each other.

\section{KEY TO THE SPECIES OF THE SUBFAMILY PONERINAE} (for the identification of workers)

1. Mandibles linear, inserted close together at the middle of the oral border; petiole terminating in a spine or point above

Mandibles inserted at the corners of the head; petiole rounded or flattened above _.................

2. No oblique swellings starting from the eyes to border the antennal fossae; the latter not confluent_--On each side of the face an oblique swelling extending out from the eye and bordering the antennal fossae $-{ }^{2}$

3. Mandibles short, broadened in their distal part and Anochetus (A.) mayri Emery Mandibles long, not broadened in their distal part, denticulate along the entire inner margin

Anochetus (S.) emarginatus subsp. testaceus

Forel

4. Body deep black throughout; large and robust ants_Odontomachus haematoda Linn.

Body of variable color

5. Dorsal surface of the epinotum, the petiole, and the fe- mora brownish-red; large and robust ants Odontomachus haematoda var. notata Mann Head paler; petiole with a shorter and less acuminate spine; size smaller _._. Odontomachus haematoda var. ruginodis Whlr. 
6. Insertions of the antennae remote; clypeus flat; claws pectinate Platythyrea punctata F. Smith Insertions of the antennae approximated; claws simple

7. Middle and hind tibiae with two spurs each

Middle and hind tibiae with a single spur each Euponera (T') stigma Fabr.

8. Body very glabrous _...... Ponera ergatandria Forel Body opaque or subopaque

9. Head with numerous punctures which give the general surface a subopaque effect _......_._._._._._...

Head with fewer punctures which give the general surface a more glabrous appearance__Ponera trigona var. opacior Forel 10. Petiole viewed from the side distinctly rectangular shaped, almost as wide dorsally as ventrally_..-Ponera opaciceps Mayr Petiole viewed from the side very distinctly narrower dorsally than ventrally _...-.-Ponera opaciceps var. jamaicensis Aguayo

\section{SUBFAMILY PONERINAE}

2. Platythyrea punctata F. Smith.

Cat. Hymen. Brit. Mus., Vol. 6, p. 108, 1858. Worker, Male Between Arecibo and Utuado (W. M. W.) ; Mayagüez (M. R. S.)

This ant, which is common throughout the West Indies, seems to prefer to nest in well-shaded locations. I have found it nesting in stumps and logs in colonies of only a hundred or two hundred individuals. The highly predacious workers forage singly on the ground or even up the trunks of trees. When alarmed they run with considerable speed.

The worker, although black, has such a dense coat of pubescence on its body that the latter imparts a pruinose or metallic effect. As the name indicates, the body is covered with numerous and conspicuous punctures.

3. Euponera (T.) stigma Fabr.

Syst. Piez., p. 400, 1804. Queen

Culebra (W. M. W.) ; Utuado (W. M. W.) ; Mayagüez, Maricao Insular Forest (M. R. S.)

This species nests by preference in well-rotted stumps and $\operatorname{logs}$, or in the soil beneath stones in shaded areas. These ants 
seem to like abundant moisture and are most often found near the bases of stumps. The colonies comprise only a few hundred individuals. Cocoons are light yellowish or sulphur colored. Specimens have been taken at altitudes as high as 3,500 feet. Workers, although predacious, are not commonly seen foraging openly in the woods like some of the Odontomachus and other ants. The workers are also slower of movement than some of the other Ponerine ants. On October 1 and November 20 both winged males and winged females were noted in a nest. The former are exceedingly active.

The worker is very deep brown or blackish with lighter appendages. The meso-and metapleurae are longitudinally straited, and the epinotum is laterally compressed.

\section{Ponera ergatandria Forel.}

Trans. Ent. Soc. London, p. 365, 1893. All castes.

Utuado (W. M. W.) ; Guayama, Sabana Grande, Lajas ( $H$. L. D.) ; Ensenada, Mayagüez (M. R. S.)

This species appears capable of living in both very arid and moist habitats. I have found colonies nesting in the soil and in decaying logs and stumps, and Dozier has collected workers from cow dung on numerous occasions. Like the Ponerine ants previously mentioned, the workers are predacious and the colonies small. As the specific name indicates, this species has males in which both worker and male characters occur in the same individual.

$P$. ergatandria seems to be a common species in the islands of the. West Indies.

The worker is characterized by its very short antennal scapes, which lack considerably of reaching the posterior border of the head, its small size $(2.5-2.7 \mathrm{~mm}$.), its glabrous appearance, and peculiarly shaped petiole.

\section{Ponera opaciceps Mayr.}

Verh. Zool. Bot. Ges. Wien., Vol, 7, p. 536, 1887. Worker, Male.

Culebra (W. M. W.) ; Utuado, Monte Morales, Monte Man- 
dios, and Coamo Springs (W. M. W.) ; Sabana Grande, Lajas (H. L. D.) ; Mayagüez, Ensenada (M. R. S.)

This is probably the commonest species of Ponera in Puerto Rico. Its habits are similar to those of the preceding species. Specimens have also been collected from beneath cow dung at frequent intervals.

The worker, which is from 3 to $3.2 \mathrm{~mm}$. in length, is black with light brown appendages; its head is opaque, and the petiole when viewed from the side is rectangular shaped, that is, not shorter dorsally than ventrally.

\section{Ponera opaciceps var. jamaicensis Aguayo.}

Bull. Bklyn. Ent. Soc., Vol. 27, pp. 216-217, 1932. Worker

Ensenada (H. L. D.) ; 18 kilometers north of Yauco (M. R. S.)

I have referred to this variety a number of specimens collected in the above-mentioned localities. These differ from typical specimens of opaciceps in the following characters: (1) shorter antennal scape, (2) narrower petiolar border, (3) more glabrous body surface, etc. Workers have been collected from the same type of habitats and under the same conditions as those of the species.

\section{Ponera trigona var. opacior Forel}

Trans. Ent. Soc. Lond., Pt. A, pp. 363-364, 1893. Worker, Queen.

14 kilometers east of Mayagüez (M. R. S.)

This species has habits similar to those of opaciceps and ergatandria. The ants are recorded from Cuba, Jamaica, and the Dominican Republic in the West Indies.

The worker of opacior can be distinguished from the worker of opaciceps by the shape of its petiole and the sculpturing of the head, and from the worker of ergatandria it is distinguished by its longer antennal scapes, less giabrous body, and rounder epinotal declivity.

\section{Anochetus mayri Emery}

Ann. Mus. Civ. Genova, Vol. 21, p. 378, 1884. Worker 
Utuado, Vega Baja, Monte Morales, Monte Mandios, Coamo Springs, San Juan, Adjuntas, Arecibo (W. M. W.) ; Mayagüez, Maricao, Arecibo, Maricao Insular Forest (M. R. S.)

This ant seems to be the most common species of the genus in the West Indies. Colonies are exceedingly small, comprising only a few individuals. Although the ants seems to nest by preference in shaded areas, I have also found them colonized in the open. Their colonies may be found either in the soil or in the decaying wood of stumps and logs. The workers, which are slow of movement, forage singly. Cocoons are light yellowish, with a black spot at one end. Several winged queens were noted in a nest on August 10.

The characters given in the key to the species clearly distinguish this species from the following one.

9. Anochetus emarginatus subsp. testaceus Forel.

Trans. Ent. Soc. Lond., p. 356, 1893. Worker, Male Culebra (W. M. W.)

I have not encountered this ant on the western end of the Island of Puerto Rico where I have done most of my collecting. This species may occur, however, on the eastern end of the Island.

Wheeler states that he found "several colonies nesting under stones in the shade of trees along the dry arroyos on the higher part of the Island of Culebra." $\mathrm{He}$ also states that the colonies are smail, numbering only from about thirty to a hundred individuals.

\section{Odontomachus haematoda Linn.}

Syst. Natur., Ed. Vol. 10, p. 582, 1758 Worker

Arecibo, Utuado, Monte Morales, Monte Mandios, Adjuntas, Vega Baja, Aibonito, Coamo Springs (W. M. W.) ; San Germán, Mayagüez, 10 kilometers northwest of Ponce, 18 kilometers north of Yauco (M. R. S.)

This species nests by preference in shaded areas. It is very common in the coffee groves of the hills and mountains. Colonies may be found in the soil or in the well-rotted wood of 
logs and stumps. Most of the nests appear to contain several hundred individuals. The workers have foraging habits similar to the species mentioned above. A large number of winged queens were found in a nest on March 20 and males on April 5. The workers can leap several inches by closing their widely opened mandibles suddenly, thus making a clicking sound in doing so. Their sting, although slightly painful, does not last long.

The typical worker of this species is large and robust, and of a deep blackish color, with slightly lighter appendages.

11. Odontomachus haematoda var. notata Mann.

Bull. Amer. Mus. Nat. Hist., Vol. 42, p. 404, 1920. Worker Monte Mandios (W. M. W.)

I have not encountered any specimens which I could positively refer to this variety. This form is only a color variation of the species and was collected by Wheeler from a high peak.

The characters given in the key to the species will serve to distinguish this ant from the typical haematoda.

12. Odontomachus haematoda var. ruginodis Whlr.

Bull. Amer. Mus. Nat. Hist., Vol. 21, p. 82, 1905. Worker, Queen

Utuado, Adjuntas, Coamo Springs (W. M. W.) ; Guánica (D. L. Van D.) ; Rio Piedras (G. N. W.) ; Vieques Island (collector?)

This variety is not as common as haematoda. The ants differs from the latter by preferring for nesting sites open, sunny areas, especially river bottoms.

Characters given in the key wijl aid in distinguishing thís species.

\section{SUBFAMILY PSEUDOMYRMINAE}

13. Pseudomyrma flavidula F. Smith.

Catalog. Hymen. Brit. Mus., Vol. 6, p. 157, 1858. Worker

Tallaboa (W. M. W.) ; Lajas (H. L. D.) ; Las Marías, Mayagüez, and Mani Beach, 4 miles north of Mayagüez (M. R. S.)

This species usually nests in the branches and twigs of trees, the stems of plants, or occasionally in crevices beneath 
bark. Colonies are not large, consisting of only a few dozen to several hundred individuals. The workers diligently run over plants in search of honey-dew excreting insects. They have been commonly noted attending the green and hemispherical scales on coffee. Undoubtedly the ants are also highly predacious.

The worker of this species can be recognized by its narrow, elongate body, exceedingly large eyes, general yellow color, and on the gaster the presence of a pair of prominent black spots near the base.

\section{KEY TO THE SPECIES OF THE SUBFAMILY MYRMICINAE}

(for the identification of workers and soldiers)

1. Antennae $4-6$ segmented

Antennae with more than 6 segments

2. Antennae with 4 segments Epitritus emmae Emery

Antennae with 6 segments

3. Mandibles long and slender, close together at their insertions, with only two borders, an internal and an external, usually parallel or subparallel and overlapped by the clypeus only at their bases..-Mandibles shorter, some distance apart at their insertions, with three borders, i. e., with the internal border differentiated into a basal and a more apical (masticatory) border, and overlapped for a considerable distance by the anterior border of the clypeus _..._._._-_Strumigenys membranifera subsp. simillima Emery

4. Inner borders of mandibles without teeth but with a series of minute denticles _-_- Strumigenys eggersi

Emery

Inner borders of mandibles with teeth

5. Inner border of mandibles with a single subapical tooth Strumigenys louisianae var. obscuriventris Whlr.

Inner border of mandibles with two long, and approxmated teeth near the apex_-_-_._-_Strumigenys rogeri Emery

6. Postpetiole articulated to the dorsal surface of the gaster, which is flattened dorsally, more convex ventrally and acutely pointed_._- Crematogaster steinheili Forel

Not as above

7. Workers strongly dimorphic, that is, without intermediates connecting the extreme forms; antennal 
club 3-segmented

Workers monomorphic; or else polymorphic, that is, with mediae intermediate between the major and minor forms

8. Head very strikingly elongate and with subparallel sides; all parts of body except appendages smooth and shining Pheidole subarmata var. borinquenensis Whlr.

Not as above

9. Clypeus carinate, also transversely rugulose

Not as above

Pheidole fallax jelskii var. antillensis Forel

10. Entire head sculptured, opaque, except the region immediately surrounding the occipital foramen, which is smooth and shining _........- Pheidole flavens subsp. sculptior Forel Only anterior three-fourths of the head sculptured, and opaque

11. Antennal scrobe of the head well defined and with a distinct lateral carina Pheidole flavens subsp. exigua Mayr.

Not as above

12. Anterior border of gula with two distinct teeth Pheidole moerens Whlr. Anterior border of gula without teeth...... Pheidole megacephala Fabr.

13. Antennae with 10 segments, the last two segments forming a distinct club

Antennae with more than 10 segments

14. Workers polymorphic, i. e., with major, intermediate, and minor forms _-_-Solenopsis geminata Fabr.

Workers monomorphic

15. Postpetiole exceedingly large; transversely elliptical in shape and distinctly broader than long-

Not as above globularia var. desecheoensis Mann.

Only the posterior portion of the head, the pronotum, and the whole, or nearly the whole of the first gastric segment dark brown, in some specimens almost black Solenopsis globularia var. borinquenensis Whlr.

17. Entire body black and shining - Solenopsis picea Emery Not as above

18. Clypeal border without teeth; body yellow excepting the posterior portion of the head and the first gastric segment which are slightly infuscated Solenopsis azteca var. pallida Whlr. 
Clypeal border with teeth; color arrangement not as above _._._._. Solenopsis corticalis Forel

19. Epinotum unarmed _. 20

Epinotum armed _._._._._._._._._. 24

20. Hairs of the body appressed, scale-like; antennal foveae prolonged to the corners of the head.....-

Cyphomyrmex rimosus subsp. minutus Mayr.

Not as above

21. Workers polymorphic; head, though shining, with well scattered, prominent punctures

Monomorium destructor Jerdon

Workers monomorphic

22. Body uniformly deep brownish black to jet black_-Monomorium carbonarium subsp. ebeninum Forel

Body of a different coloration _...........-...-.

23. Only the head and gaster dark brown or blackish Monomorium floricola Jerdon

Entire body yellow, excepting for a slight infuscation at the base of the gaster. Monomorium pharaonis Linn.

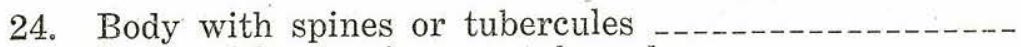

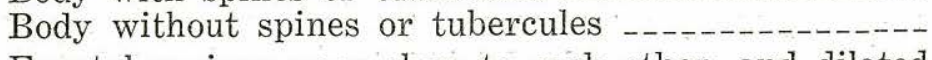

25. Frontal carinae very close to each other, and dilated at the anterior extremity; clypeus not distinctly prolonged back between them_-__Myrmicocrypta brittoni Whlr.

Frontal carinae separated, embracing the posterior extremity of the clypeus Trachymyrme: jamaicensis André

26. Clypeus armed with only two longitudinal ridges_-..-Rogeria curvipubens Emery

Clypeus not as above

27. Antennal scrobes bordered below by a carina of the cheek _.....- Wasmannia auropunctata Roger Antennal scrobes not bordered below by a carina of the cheeks

28. Posterior margin of the clypeus elevated in the form
of a welt or ridge bordering the antennal fossa in front

Not as above

Tetramorium lucayanum Whlr.

29. Body black

Body not not black

30. Head, thorax, petiole and postpetiole coarsely rugosereticulate; hairs on thorax simple.

Tetramorium guineense Fabr.

Sculpture finer; hairs on thorax short and clavate.-Tetramorium simillimum F. Smith 
31. Antennae 11-segmented, frontal carinae close to each other and dilated at the anterior extremity

Mycocepurus smithi var. borinquenensis Whlr. Antennae 12 segmented; frontal carinae neither closely approximated nor dilated anteriorly

32. Middle and hind tibiae without spurs; petiole with long cylindrical peduncle and a broad oval node; postpetiole unusually large; body hairs simple

Not presenting all the above characters; either the spurs present, or the body hairs clavate

33. Size 2.2 to $2.5 \mathrm{~mm}$; head black_..._._ Cardiocondyla venustula Whlr.

Size smaller; head light reddish brown; antennal scapes infuscated toward the tips_Cardiocondyla

emeryi Forel

34. General body color blue-black

Only the head, coxae, femora, and gaster blue-black--

35. Legs only slightly darker (fuscous) than the remainder of the body; size 2 to 2.5 mm.--_Macromischa albispina Whlr.

Legs much paler (yellowish white) ; size $1.5 \mathrm{~mm}$.

Macromischa albispina subsp. pallipes Mann

36. Epinotum spined Macromischa isabellae Whlr. Epinotum unarmed Macromischa isabellae mutica subsp. nov.

\section{SUBFAMILY MYRMICINAE}

14. Monomorium carbonarium subsp. ebeninum Forel.

Mitth. Munch. Entom. Ver., Vol. 5, p. 8, 1881. Worker Culebra (W. M. W.) ; Santurce, Utuado, Coamo Springs, Aibonito, Adjuntas, Arecibo, Vega Baja (W. M. W.) ; Guánica, San Sebastiáan (G. N. W.) ; Mayaguez, Lares, Las Marías (M. R. S.)

This is one of the most common ants of the West Indies. It occupies the same status in these Islands that $M$. minimum Buckley does in the United States. It forms populous colonies, which are characterized by having many reproductive queens tc a colony. Their great adaptability is indicated by the fact that the species nests in both scil and wood, back of the leaf sheaths or corn and bananas, in cabbage heads, Tillandsias, and in the fruits of Hibiscus sabdariffa. The workers are exceedingly fond of honeydew. They have been noted attending such insects as Saissetia hemispherica Targ., Coccus viridis Green, the aphid Sipha flava Forbes, etc. The ants are also highly predacious. 
Although they have not been observed infesting houses, there is little doubt that they would do so if given the opportunity.

The worker is easily recognized by its shining black or deep brownish color, 3-segmented antennal club, lack of epinotal spines, and cuboidal shaped epinotum.

\section{Monomorium destructor Jerdon.}

Madras Jour. Lit. and Sci., Vol. 17, p. 105, 1851. Worker Tallaboa (W. M. W.) ; Guayama, Sabana Grande, Ponce (H. L, D.) ; Mayaguez and Ensenada (M. R. S.)

The indications are that this species is an imported ant. Should an intensive search be made for it, the ants would probably be found in many of the seaport towns, if not elsewhere. At Mayagüez the species was found nesting in a bakery where the ants made numerous trails on the walls and floors, composed of enormous numbers of workers. Dealated queens have been seen moving along in the trails with the workers. The colonies of destructor must be composed of thousands of individuals if one is to judge from the number and size of their trails. Like $M$. ebeninum, they are polygynous. An inmate of the bakery said the ants were fond of sweets and meats, but did not seem to care for flour or lard. In a very dry and arid pasture at Ensenada the ants were found nesting in the soil at the base of trees and also in the soil under rocks. Workers have frequently been noted attending soft scales, psyllids, and other honeydew-excreting insects. They are also highly predacious.

Workers can be recognized by their yellowish color, their shining bodies, and by the fact that they are highly polymorphic.

\section{Monomorium floricola Jerdon.}

Madras Journ. Lit. and Sci., Vol. 17, p. 107, 1851. Worker

Culebra (W M. W.) ; Vega Baja, Coamo Springs, Tallaboa (W. M. W.) ; Lares, Peñuelas, Sabana Grande, San Germán, Humacao, Caguas (G. N. W.) ; Mayaguez, Ceiba Baja (M. R. S.)

This ant, unlike the two preceding species, seems to prefer wood for nesting purposes. Moderate-sized colonies have been noted in the twigs of trees, beneath the bark of trees, etc., and in Tillandsias. Like the other species of this genus floricola has many reproductive queens per colony. This species is also 
noted for producing ergatoid females, that is, females which were apparently never meant to be winged. The workers are exceedingly fond of honeydew as well as organisms. I have commonly seen the ants attending the green and hemispherical scales on coffee. The workers of this species made themselves quite objectionable by stealing insects for food from our insectary.

The worker of $M$. floricola is quite easy to distinguish by its 3-segmented antennal club; lack of epinotal spines; dark head and gaster, with light-colored thorax; and its general glabrous appearance.

\section{Monomorium pharaonis Linn.}

Syst. Natur., Ed. 10, p. 580, 1758. Worker.

Culebra (W. M. W.) ; San Juan, Arecibo (W. M. W.); Mayagüez, (M. R. S.)

This imported species, which is rapidly becoming disseminated over the entire world, has not yet been recorded many times from the Islands of the West Indies. This may be due to lack of a sufficient search for it. The ant, which is commonly known as "Pharaoh's" ant, is highly adapted for living. in urban areas, where its very populous colonies nest in the woodwork and masonry work of dweillings, stores, etc. Like other species of Monomorium, its colonies are polygynous. The ants are practically omnivorous in their feeding habits. In a country with as mild a climate as Puerto Rico this ant should be capable of living outdoors as well as inside dwellings.

The worker, which is of a pale yellowish color, is characterized by its lack of epinotal spines, presence of a 3-segmented antennal club, and punctate and subopaque appearing body. The gaster is distinctly infuscated near the base. 


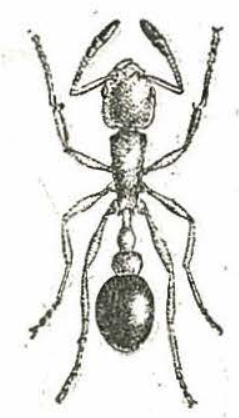

Fig. 1. Cardiocondyla emeryi Forel (After Wheeler.)

\section{Cardiocondyla emeryi Forel}

Mit. Munch. Entom. Ver., Vol. 5, p. 5, 1881. Worker

Vieques (Busck) ; Culebra (W. M. W.) ; San Juan, Santurce, Utuado, Adjuntas, Coamo Springs (W. M. W.); Sabana Grande, Lajas (H. L. D.) ; Tres Hermanos, Mani Beach, Mayagüez, Guánica, Ensenada (M. R. S.)

This is a very common species of ant in the West Indies, as numerous records indicate. It is also recorded from India, Palestine, Madagascar, Florida, etc. Due to the extremely small size of the worker and its habit of commonly foragirig alone, the species is easily overlooked by the collector. Wheeier states that " the colonies of this ant are small and occur in sandy places, especially in river or creek bottoms and on sea beaches." While it is true that they are commonly found in such habitats the species in Puerto Rico is by no means confined to such areas, for I have found them nesting in clay soils considerably removed from stream beds. Their nest entrances are extremely small and may easily be overlooked. On a number of occasions workers have been collected from cow dung. Undoubtedly the ant is highly predacious, but it is also given to attending honeydew-excreting insects to some extent.

The worker is recognized by its distinctive coloration, all of the body being light reddish brown except the gaster and the antennal club. The worker differs from that of $C$. venustu$l a$ in its more angular thoracic humeri, more slender petiole, difference in coloration, size, etc. 


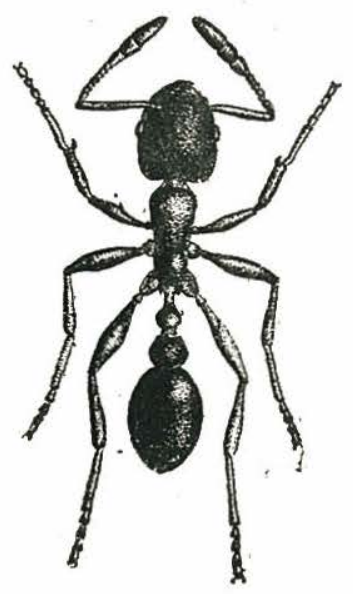

Fig. 2. Cardiocondyla venustula Wheeler. (After Wheeler.)

19. Cardiocondyla venustula Whlr.

Bull. Amer. Mus. Nat. Hist. Vol. 24, pp. 128-130, 1908. Worker, Queen.

Culebra (W. M. W.) ; Coamo Springs (W. M. W.) ; Ponce, Guayama, Coamo (H. L. D.) ; Mayagüez (M. R. S.)

This species is apparently not so common as the preceding in Puerto Rico or in any of the other West Indian Islands.

Wheeler, who described venustula from Puerto Rican specimens in 1908, remarks that the ant "is not uncommon in sandy and gravelly places, especially on the sea-beaches, where it lives in small colonies, comprising a single dealated queen and a few dozen workers, in shallow nests like those of some species of Leptothorax." He noted winged females on March 23.

Dozier collected workers on several occasions from dry cow dung in very arid pasture areas at both Ponce and Coamo. Nothing is known concerning the food of these ants but they are thought to be mainly predacious.

The worker of venustula may be distinguish from that of C. emeryi by its larger size $(2.0-2.5 \mathrm{~mm}$.), rounder thoracic humeri, broader petiole, and darker and more opaque appearance. 


\section{Solenopsis azteca var. pallida Whlr.}

Bull. Amer. Mus. Nat. Hist., Vol. 24, p. 131, 1908. Worker

Coamo Springs (W. M. W.) ; 14 kilometers east of Mayagüez (M. R. S.)

Wheeler found this ant nesting in the soil beneath a boulder in a dry stream bed. The specimens which I have referred to this species were quite common in stumps and logs in a coffee grove. They were usually found just beneath the bark. Winged queens were noted on December 13.

My specimens agree with Wheeler's brief characterization of the workers as having a yellowish body, with the vertex of the head and the first gastric segment slightly infuscated, and the presence of two well-developed ciypeal carinae, but no teeth on the clypeal border.

\section{Solenopsis corticalis Forel.}

Mitth. Munch. Entom. Ver., Vol. 1, p. 13, 1881: Worker, Queen.

Utuado (W. M. W.) ; 16 kilometers east of Mayagüez, Lajas (M. R. S.)

This species is recorded by. Wheeler as having been found nesting in the stem of a bamboo. I have referred to corticalis specimens collected from clay soil at an altitude of 650 feet. Workers have also been noted attending the pineapple mealybug. The species is not recorded from any of the other West Indian Islands except St. Thomas.

Very little is known concerning the biology of the ant.

\section{Solenopsis picea Emery.}

Bull. Soc. Ent. Ital., Vol. 28, p. 1896. Worker Queen.

Utuado (W. M. W.)

This ant is recorded only from Cuba and Puerto Rico. A single colony was found by Wheeler nesting under the bark of a rotting log.

As the name indicates, the worker is very dark, and glabrous, differing thus from the other monomorphic forms mentioned in this paper, with which it might be confused.

I have no information on the biology of the species. 
23. Solenopsis geminata Fabr.

Syst. Piez. No. 6, p. 423, 1804. Worker.

Culebra (W. M. W.) ; Arecibo, Adjuntas, San Juan, Santurce, Vega Baja, Utuado, Monte Morales, Monte Mandios, Coamo Springs, Ponce, Tallaboa (W. M. W.) ; Guánica, Lajas, Ponce, Ensenada (H. L. D.) ; Mayagüez, Juana Díaz, Tres Hermanos, Maricao Insular Forest, etc. (M. R. S.)

The "hormiga brava" is not only one of the most common ants in Puerto Rico, but also of the entire West Indies. It is perhaps better known by the natives than any other ant. Their encounters with this vicious and aggressive ant have not only resulted in their respecting it but also in giving it the name "brave ant". I have seen colonies of this ant from sea level to an altitude of approximately 3,000 feet. Although this ant prefers to nest in open sunny places, its nests on some occasions are found in lightly shaded woods. The typical nest is a mound of loose earth with several entrances leading into it, but the ants may nest in the soil beneath cow dung or in other places. Their colonies are composed of thousands of individuals. Fertile, dealated queens are capable of starting colonies unaided.

This is one of the most versatile ants known. The workers are noted for their predaciousness, as well as for their love of seeds, the juices or sap of plants, and honeydew. To one who has lived in Puerto Rico it would seem that there are very few plant lice, soft scales, mealybugs, etc., that these ants do not attend. The fostering attitude shown by the worker toward the pineapple mealybug (Pseudococcus brevipes Cockll.) makes it a very sarious problem in combating the latter insect. The "hormiga brava" is without doubt the most important ant pest in the island for the following reasons: (1) its vicious stinging habit, (2) the stealing of small seeds from seed beds, (3) the attendance on and fostering care exhibited toward honey-dew excreting insects, (4) its habit of gnawing into plants, fruits, and trees. It is also presumed that the ants may gnaw holes in clothing, kill young poultry or birds as these emerge from the egg, and invade houses as does the fire ant (Solenopsis xyloni McC.) in the southern part of the United States. 
Several specimens of a phorid fly, Pseudaceton antiguense Cwfd., were captured around the nest of a colony of this ant at a locality 17 kilometers east of Mayagüez.

The worker of the fire ant is polymorphic, is highly variable in color, ranging from reddish brown to black, glabrous, possesses a 2-segmented antennal club, and has no epinotal spines.

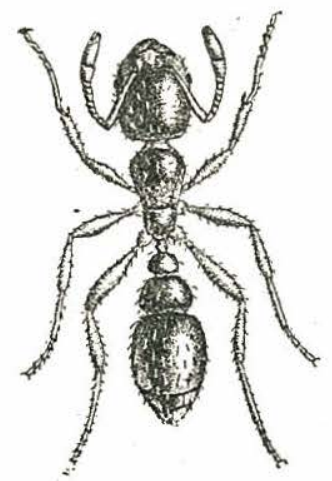

Fig. 3. Solenopsis globularia var. borinquenensis Whlr. (After Wheeler.)

24. Solenopsis globularia var. borinquenensis Whlr.

Bull Amer. Mus. Nat. Hist., Vol. 24, p. 131, 1908. Worker Culebra (W. M. W.) ; El Morro at San Juan (W. M. W.)

Wheeler, who described this variety from specimens gathered at the above- named localities, states that it "nests in the white sand of the sea beaches just above the high water mark." Although I have collected ants on numerous occasions in such places, these specimens have apparently been too dark for me to refer them, to borinquenensis, so I have assigned them to the following species instead.

This ant has been recorded from Santc Domingo as well as Haiti.

The worker is distinguished from that of the typical species in that the posterior portion of the head, the pronotum, and the whole or nearly the whole of the first gastric segment are dark brown, in some specimens almost black. 
25. Solenopsis globularia var. desecheoensis Mann.

Bull. Amer. Mus. Nat. Hist., Vol. 42, p. 428, 1920. Worker

Desecheo Island (W. M. W.) ; Ensenada, Lajas, Lake Guánica, Coamo (H. L. D.) ; Mayagüez (M. R. S.)

This species was described by Mann from specimens collected on Desechto Island, with no remarks given as to their nesting habits or biology.

Many specimens have been taken by Dozier from cow dung in dry, arid cattle pastures at the above-named localities. I have also taken workers on several occasions along the sandy beach at Mayagüez, only 10 feet or so from the Caribbean Sea. These were thought to be nesting in the soil, but I was unable to locate their nests definitely. One would judge that their colonies are not very populous, comprising perhaps only a few hundred individuals. The ants are undoubtedly largely predacious. The workers crawl very slowly and usually forage singly.

Mann states that the worker of this variety differs from that of globularia in having a jet black body and (yellowish brown) appendages.

26. Pheidole fallax jelskii var. antillensis Forel.

Mitth. Munch. Ent. Ver., Vol. 1, p. 4, 1881. Worker.

Culebra (W. M. W.) ; Utuado, Monte Morales, Monte Mandios, El Morro at San Juan, Santurce, Coamo Springs, Vega Baja (W. M. W.) ; Tres Hermanos, Mayagüez, Hormigueros, Ensenada, Maricao Insular Forest, Juana Díaz (M. R. S.) ; Toa Baja, Yauco, Río Piedras (G. N. W.) ; Lajas, Sabana Grande, Ponce, Coamo, Humacao (H. L. D.)

This is not only one of the most common ants in Puerto Rico but also in the entire West Indies. I have seen colonies in Puerto Rico from sea level to approximately 3,000 feet altitude. The fairly populous colonies are usually found in open, sunny areas regardless of whether these be bare or grassy. The nest can be easily recognized by the peculiar elongate, slit-shaped entrance holes. The ants are so versatile that they even nest in the cracks of pavement, the crannies of masonry work, etc. The rather large, slender workers of this species can be observed bringing into the nest literally hundreds of insects and other 
organisms. Their food is largely flesh, and so strongly does this predominate that the ants have a distinct fecal odor. Workers have been collected very frequently from dung, and it is believed that the ants live to a large extent on the insects that inhabit this material. I have noted the workers on several occasions attending the green and hemispherical scales, the aphid, Pentalonia nigronervosa Coquerel on bananas, etc., thus indicating that the die $e_{i}^{\leftarrow}$ of this ant is not entirely flesh. A. H. Madden found both workers and soldiers in the stomach of the Surinam toad, Bufo marinus.

On August 14 queen pupae were noted in a colony, and on December 18 winged males and winged queens.

The soldier of $P h$. antillensis is easily distinguished from the soldiers of other Puerto Rican species of Pheidole by its large size and reddish-brown body. The head of the soldier is very coarsely rugulose-recticulate and subopaque.

\section{Pheidole flavens subsp. exigua Mayr}

Horae Soc. Entom. Ross., Vol. 18, p. 36, 1884. Soldier

Utuado, Monte Mandios, Coamo Springs (W. M. W:) ; 14 kilometers east of Mayagüez, (M. R. S.) ; Cayey (G. N. W.)

This species is apparently not so common in Puerto Rico as some of the other forms of the genus. So far it has not been recorded from any of the other West Indian Islands. Wheeler found colonies of this ant nesting in the soil beneath stones and logs in coffee groves. I have noted the ants on two occasions in a similar habitat nesting in rotten stumps and also in the ground at the base of a stump. The colonies appear to be very small, being composed of only a few hundred individuals. The ants are without doubt principally flesh feeders.

The soldier of exigua, as its specifiic name indicates, is easily recognized by its distinct antennal scrobe, which is set off from the remainder of the head by a well-defined lateral carina. The anterior three-fourths of the head is subopaque; the color of the head, thorax, and pedicel is pale reddish brown. The queen is unusually small and dark colored. 
28. Pheidole flavens subsp. sculptior Forel

Trans. Ent. Soc. Lond., p. 414, 1893. Soldier, Worker, Queen

Coamo Springs (W. M. W.) ; 4 miles east of Mayagüez, 6 miles southeast of Mayagüez (M. R. S.)

Small colonies of this ant have been found on a number of occasions in rotten stumps in coffee groves. A colony was also collected from the sandy soil of the beach beneath a coconut husk. The food habits of this ant are probably the same as those of the preceding species. Winged queens were found in colonies on August 23, September 20, and October 4. Winged males were noted in similar circumstances on August 14 and October 14.

The characters mentioned in the key to the species will serve to distinguish the soldier of this ant from that of the soldier of other species of Pheidole.

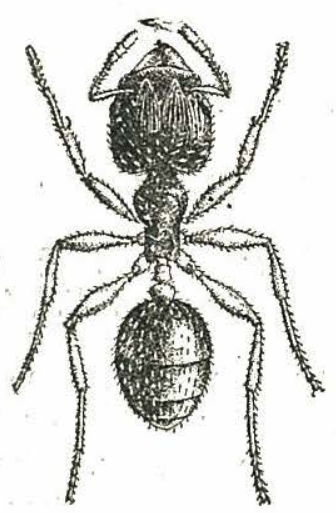

Fig. 4. Pheidole moerens Wheeler: soldier. (After Wheeler.)

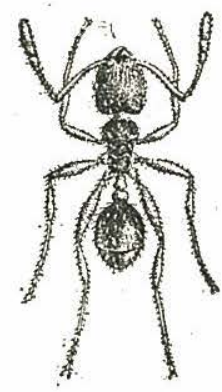

Fig, 5. Pheidole moerens Wheeler: worker. (After Wheeler.)

\section{Pheidole moerens Whlr.}

Bul. Amer. Mus. Nat. Hist., Vol. 24, p. 136-137, 1908. Soldier, Worker

Culebra (W. M. W.) ; Utuado, Monte Morales, Monte Mandios (W. M. W.) ; Ponce, Coamo (H. L. D.) ; Yauco, Mayagüez, Maricao Insular Forest (M. R. S.) 
Although this is one of the commonest species of Pheidole in Puerto Rico, it has not yet been recorded from any of the other West Indian Islands. I have found it especially abundant in the hills and mountains, particularly in coffee groves. The species has been taken at altitudes as high as 3,000 feet. The small colonies of moerens may be found in the soil beneath stones or $\log _{\mathrm{s}}$, or in the wood of $\log _{\mathrm{s}}$ and stumps. Often the ants nest in the very soft, moist wood. None of the soldiers and workers have been observed attending scales and plant lice, hence it is inferred that the ants are principally if not exclusively flesh feeders. Winged males were seen in a colony on November 21, and both winged males and winged queens on March 24.

The soldier can be recognized by the posterior fourth of the head being smooth and shining, the gula having two prominent teeth, the prothorax transversely rugulose, and the dorsal surface of the postpetiole glabrous.

\section{Pheidole megacephala Fabr.}

Ent. Syst. Vol. 2, p. 361, 1793. Soldier

Culebra (W. M. W.) ; Aibonito, Arecibo, Mayagüez (W. M. W.) ; Río Piedras ,Cayey (G. N. W.) ; Mayagüez (M. R. S.)

This imported species, so far as I know, is confined to the towns in Puerto Rico. Undoubtedly the ants occur in many more localities than are mentioned above. The species is also well scattered throughout the West Indian Islands. I found the ants in my back yard nesting in the soil beneath stones and in cracks beneath the concrete walks. On numerous occasions they were noted foraging in the kitchen. On the roots of the grass Eleusine indica they were noted attending the pineapple mealybug (Pseudococcus brevipes). The ants are fond of honeydew in spite of their love for flesh. A colony has numerous fertile queens in it, thus accounting for its populousness. $P$. megacephala is apparently a mortal enemy of the "hormiga brava", as these two species have been seen fighting on numerous occasions.

On January 28 many winged males were noted in a colony.

The soldier is recognized by its exceedingly large head, almost the entire posterior half of which is smooth and shining, 
the gula has no teeth, the epinotal spines are acute, and the postpetiole is sharply conulate on the sides; the color is a deep brown, with the apical section of the gaster darker.

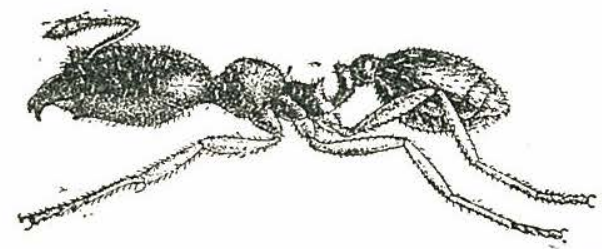

Fig. 6. Pheidole subarmata var. borinquenesis Wheeler: soldier. (After Wheeler.)
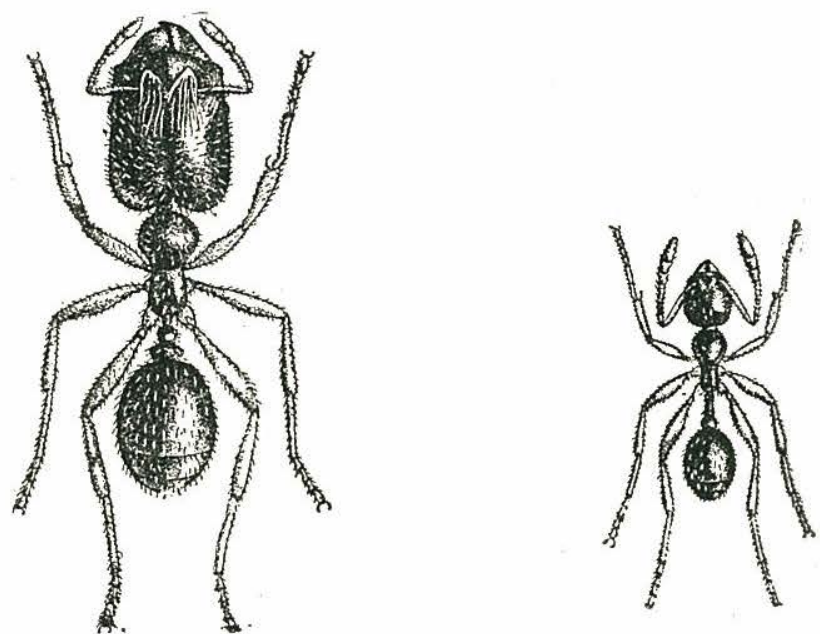

Fig. 7. Pheidole subarmata var. Fig. 8. Pheidole subarmata var borinquenensis Wheeler: soldier. (After Wheeler.) borinquenensis Wheeler: worker. (After Wheeler.)

31. Pheidole subarmata var. borinquenensis Whlr.

Bull. Amer. Mus. Nat. Hist., Vol. 24, p. 133-134, 1908 Soldier, Worker.

El Miorro at San Juan, Santurce, Utuado (W. M. W.) ; Hatillo, Lajas, Sabana Grande (H. L. D.) ; Mayagüez, Juana Diaz: Tres Hermanos, Lares (M. R. S.)

This rather common species of Puerto Rican ant has not yet veen recorded from any of the other West Indian Islands Wheeler states that the formicaries "are small craters throwr up in sandy, sunny places like roads and creek bottoms." $\mathrm{H} \epsilon$ 
also remarks that there are only a few soldiers and workers in a colony. I have found the ants nesting in both clay and sandy soils. Madden noted the soldiers and workers feeding on the eggs and nymphs of the mole cricket Scapteriscus vicinus. Latr. He also took these ants from the stomach of the Surinam toad. Dozier found the soldiers and workers quite common in cow dung. I have noted the ants attending the pineapple mealybug, the aphid Pentalonia nigronervosa on plantain, the green and the hemispherical scales, etc.

The soldier of this species is very easily distinguished by its very elongate head, the borders of which are subparallel; the considerably elevated frontal carinae and the smooth, glabrous surface of the body.

\section{Crematogaster steinheili Forel}

Mitth. Munch. Entom. Ver., Vol. 1, p. 15, 1881. Worker

Culebra (W. M. W.) ; Coamo Springs, Vega Baja, Aibonito (W. M. W.) ; Guayama (J. D. M.) ; Fajardo (G. N. W.) ; Ensenada, Mayagüez, San Germán, Lajas, Guánica (M. R. S.)

C. steinheili is the only species of Crematogaster that has been taken in Puerto Rico to date. It is not only a fairly common ant in Puerto Rico but it is also common in many of the other West Indian Islands. Colonies which are moderately populous and contain many fertile queens are found in rotten wood, in cavities in twigs of plants, under the bark of trees, at the base of and between the leaf sheaths of Tillandsias, etc. On one occasion a nest was found in the soil beneath a rock. I have found the ants in some of the driest areas of the island as well as some of the most moist, hence am led to conclude that it is a highly adaptable species.

The workers are exceedingly fond of honey-dew. They have been noted on numerous occasions attending mealybugs, soft scales, and plant lice. It is a very common custom with this species to built a carton like covering over the insects which they are attending. Many of the honey-dew excreting forms attended are economic species, such as a Aphis gossypii Glov., Pseudococcus nipae Mask., Ps. brevipes, and Toxoptera aurantiae Koch. The ants are probably flesh feeders also. When alarmed the worker has the habit of turning up the posterior portion of its gaster, like many of the other ants of the genus. 


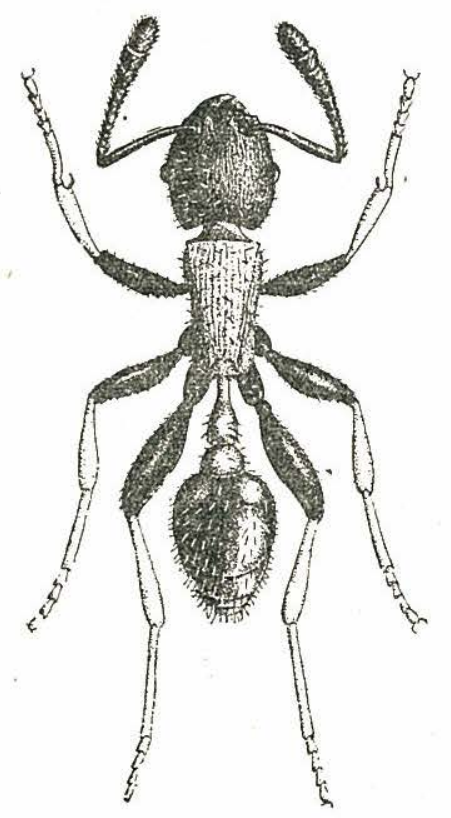

Fig. 9. Macromischa isabellae Wheeler (After Wheeler.)

33. Macromischa isabellae Whlr.

Bull. Amer. Mus. Nat. Hist., Vo!, 24, pp. 138-139, 1908. All castes.

Monte Morales, Monte Mandios (W. M. W.) ; Lares, Yauco, (F. Sein) ; Las Mesas near Mayagüez (M. R. S.)

This beautiful species is one of the few members of the genus found in Puerto Rico, although the ants are very common in other West Indian Islands, especially Cuba. There seems to be little doubt that $M$. isabellae prefers high elevations for its nesting sites and thrives best in rather densely wooded areas. The ants have been noted at altitudes ranging from about 800 to 3,000 feet. Wheeler found the colonies very small and the ants nesting in a hollow twig and under the roots of an epiphytic orchid. Wolcott records them as nesting in an old stump. I found a colony comprising perhaps 75 to 100 individuals nesting in a branch of a tree in galleries and chambers that may have been previously constructed by some wood-boring beetle. The workers have a habit at times of bending the gaster down- 
ward and forward between the legs in a very peculiar manner. When one sees such an ant it immediately gives the false impression that the ant has been unfortunate enough to lose its gaster. Nothing is known concerning the food of the ant, although the species is an arboreal type. Careful examinations of workers from a single colony show that the length of the epinotal spines of this species is highly variable, a point that has much taxonomic significance in reference to the status of several subgenera which have been created for these taxonomically perplexing ants.

Sein took winged males of this ant at Yauco on August 24 I have seen both winged males and male pupae in a nest near Mayagüez on March 15.

The peculiar and beautiful color markings of the worker of this species easily distinguishes it from any other Puerto Rican ant.

34. Macromischa isabellae mutica subsp. nov.

Maricao Insular Forest.

Worker: Length 3.5 to $3.7 \mathrm{~mm}$.

Head rectangular, distinctly longer than broad, sides subparallel, posterior border very faintly emarginate, and eyes slightly in front of the middle. Mandibles 5-toothed. Antennal scapes extending a slight distance beyond the posterior angles of the head; segments 3 to 7 of the funiculus apparently broader than long, the terminal segment as long as the two preceding segments taken together. Thorax considerably less than three times as long as broad; broader in front than behind, and with a straight, transverse carina on the pronotum ending on each side in the angular humerus. In lateral profile the thorax is without sutures and terminates posteriorly in a well-arched epinotum that is devoid of any trace of spines. Petiole from above not more than twice as long as broad, pedunculate, gradually broadening behind; in profile the anterior surface of the node is slightly concave, the posterior surface slightly convex, and the node well rounded and high. Postpetiole, from above, very distinctly broader than long, nearly as broad in front as behind. Gaster small. Legs long, femora incrassated and increasing in size from the first to the third pair. 
Opaque; gaster glabrous. Mandibles with coarse longitudinal striations. Clypeus, head, thorax, petiole, and postpetiole very finely and densely punctate, thus giving these parts a velvety appearance. Clypeus, head, and thorax with faint longitudinal rugae, the rugae on the thorax farther apart than those on the head.

Hairs whitish; sparse, more prominent on the head, thorax, petiole, postpetiole, and gaster, more slender and appressed on the appendages.

Head, antennae, coxae, femora, and gaster blue-black. Thorax, petiole, and postpetiole dull orange red; tips of mandibles, tibiae, tarsi, and two elliptical spots at the base of the first gastric segment yellow.

Described from 19 workers collected at the Maricao Insular Forest on August 18, 1935, at an altitude of 3,000 feet. Cotypes in the collections of the United States National Museum and the writer.

The worker of this new subspecies can be distinguished from that of isabellae by the following characters:

(1) absence of epinotal spines, hence the specific name, mutica,

(2) head with a faintly emarginate posterior border,

(3) petiole not more than twice as long as broad,

(4) thorax lacking considerably of being three times as long as broad, and

(5) petiole with a faint ventral tooth anteriorly.

This new subspecies is of more than ordinary interest in that it sheds considerable light on the taxonomic status of several subgenera formerly proposed for this perplexing group of ants. Roger recognized the variable characters of these ants when he erected the genus Macromischa for them, thus indicating by the name of the genus that the species included under it were very diverse, or a large mixture of variable forms.

In 1920 Mann made a very creditable attempt to clarify the situation by taking all the known forms of Macromischa and dividing them into three subgenera: (1) those with unarmed epinota and elongated petiolar peduncles, subgenus Croesomyrmex, (2) those with rectangular heads and short 
peduncles to the petiole, subgenus Antillaemyrmex, and those remaining, subgenus Macromischa sensu strictu. Wheeler in 1931 went so far as to elevate the subgenera Croesomyrmex and Antillaemyrmex to distinct genera, although he states that the status of the two is perhaps doubtful "because at least one species of Macromischa sensu str., namely pastinifera Emery, is terricolous, according to Creighton, and one species of Antillaemyrmex (floridanus) lives in twigs, and because the species melanocephala is very much like an Antillaemyrmex, except in the shape of the petiole."

Thus, the finding of the new subspecies mutica described above again complicates the situation regarding the forms of Macromischa and would seem to indicate that the characters suggested for these subgenera or genera (according to whether one considers Mann's interpretation or that of Wheeler's) are too highly variable and elusive, and it is better, once again, to consider all species of Macromischa as belonging to a single genus.

My examinations of many specimens of $M$. isabellae collected from a single colony in Puerto Rico show that the amount of development of the epinotal spines is highly variable among these specimens. The finding of mutica, however, shows the absolute futility of retaining the subgenera Macromischa and Croesomyrmex, since worker specimens of Wheeler's isabellae would fall, because of their spined epinotum and slender pedicel, into the subgenus Macromischa, and the worker of mutica, because of their unarmed epinotum, into the subgenus Croesomyrmex. This condition could never exist, since we have here the peculiar anomaly of having the primary form (isabellae) falling into one subgenus and that of its variant or derivative (mutica) into another subgenus. For these reasons I would propose that all subgenera of Macromischa be dropped and all the species in it retained in an undivided genus until a better classification can be provided.

The habits of this new form are so similar to those of the preceding species that they need not to be discussed in detail here. On several occasions the ants have been collected in the Maricao Insular Forest at an altitude of approximately 3,000 ft. Here workers were collected from the surface of the ground and from the trunks of trees as they were foraging singly. Not only do the workers have the same habit of tucking the gaster 
beneath the body as with $M$. isabellae, but also when disturbed they crouch down on a surface and remain very quiescent. A small colony was found in the soil beneath a stone. Callows in this nest were noted to carry immature stages around in their mouths, exactly like the fully developed workers.

Nothing is known concerning the feeding habits of these ants.

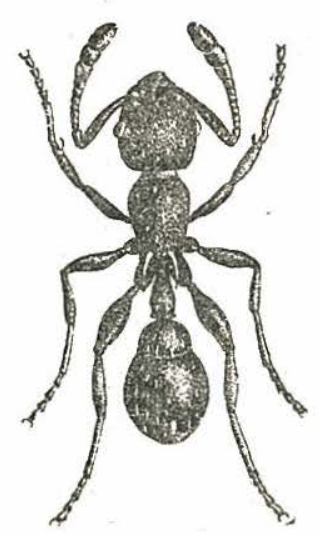

Fig. 10. Macromischa albispina Wheeler (After Wheeler.)

35. Macromischa albispina Whlr.

Bull. Amer. Mus. Nat. Hist., Vol. 24, pp. 139-140, 1908. Worker, Queen.

Culebra (W. M. W.)

This species has been taken only once in the West Indian Islands, and that time from Culebra, a small Island off the southeast coast of Puerto Rico. It was described in 1908 by Wheeler from specimens taken nesting "in a small cavity in the ground in the shade of a thicket, where some of the workers were moving about slowly over dead leaves and twigs."

Very little is known of biology of this ant, except that the colonies are small and inhabit the soil. It is inferred that the workers are flesh feeders.

The worker is characterized by a general blue-black body color and very distinctly white epinotal spines. The color of the latter suggested the very typical specific name albispina. 
36. Macromischa albispina subsp. pallipes Mann.

Bull. Amer. Mus. Hist., Vol. 42, p. 424, 1920. Worker, Queen

\section{Mona Island (Mann)}

First described by Mann from Mona Island of the coast of Puerto Rico as a variety of $M$. albispina, this ant was later raised to subspecific status by Wheeler. The latter states that the worker and queen of pallipes are smaller than those castes of the species. He also remarks that the worker of pallipes has the legs, antennal scapes, and mandibles yellowish white, and petiolar node distinctly smooth and shining. The antennal funiculi are slightly brownish.

The biology of pallipes is very probably similar to that of the species.

\section{Rogeria curvipubens Emery.}

Bull. Ent. Soc. Ital., Vol. 26., p. 54, 1894. Worker Queen. Ensenada (M. R. S.)

I have referred to this species a single specimen that was captured from the soil beneath a rock in a dry pasture of one of the most arid areas of the Island. Although I hunted assiduously for other specimens, none could be found.

R. curvipubens has also been collected in the Bahamas, Cuba, and the Virgin Islands. It is apparently a rare ant on the western end of the Island of Puerto Rico.

Nothing is known of the biology of this ant, but it is believed that it forms very small colonies, is subterranean in habits, and is largely a flesh feeder.

The worker, which is less than $2 \mathrm{~mm}$. in length, is of a dark reddish-brown color. The antennae are 12-segmented, the clypeus carinate, the eyes extremely small, the epinotum bispinose. I could not devect any spurs on the hind tibiae. The affinities of this ant seem to lean strongly to those of Stenamma.

38. Tetramorium guineense Fabr.

Entom. Syst., Vol. 2, p. 357, 1793. Worker.

Culebra (W. M. W.) ; Hatillo, Humacao (H. L. D.) ; Yabucoa (G. N. W.) ; Mayagüez, Mani Beach near Mayagüez (M. R. S.) 
This introduced species is undoubtedly much more widely distributed in Puerto Rico than the above records would indicate. One would expect to find the ants most commonly in the towns, especially those that are seaports. T. guineense is also very widely distributed throughout many of the other West Indian Islands. Several colonies of this species became established in one of our insectaries and gave considerable trouble by feeding on the larvae and pupae of the West Indian fruit fly, as well as some of the other insects. I found a colony of this ant nesting in a rotten coconut log near the beach. Winged males were noted in this nest on September 17. Colonies of this ant apparently do not number over several hundred individuals. The workers feed on flesh as well as on honeydew. On a number of occasions they have been taken from cow dung. Although this species has not been noted infesting houses in Puerto Rico, there is little doubt that it would if the opportunity were given. Wheeler records it as feeding on a broken papaya.

The very coarse, rugose-reticulate scuipturing of the head, thorax, petiole, and postpetiole of the worker, and its larger size, help to distinguish it from the worker of the following: species of Tetramorium.

\section{Tetramorium lucayanum Whlr.} Worker.

Bull. Amer. Mus. Nat. Hist., Vol. 21, pp. 100-101, 1905.

Mayagüez, 4 miles from Mayagüez (M. R. S.)

This species, first described by Wheeler from specimens taken in the Bahamas, has since been taken from Cuba and Haiti and will probably be found to occur in many of the other West Indian Islands.

Mann records this species as nesting in the soil in small colonies beneath stones. I found a colony of lucayanum nesting beneath the bark of an old guaba stump very near the base, in a coffee grove, only a few miles from Mayaguez. Specimens of this ant have also been collected from a crack in the concrete floor of a barn on the Puerto Rico Agricultural Experiment Station grounds. T. lucayanum is probably the only species of the genus that is native to the island. Almost nothing is known of the biology of this ant. It is believed that the workers feed mainly on flesh. 
The worker is distinguished from those of the other members of the genus here mentioned by its very characteristic, quadrangular (when viewed in lateral profile) petiole, its black, shining body, and its size (2.25-2.5 mm.).

\section{Tetramorium simillimum Nylander}

List Brit. Animals, Brit. Mus., part 6, p. 118, 1851. Worker Culebra (W. M. W.) ; Coamo Springs (W. M. W.) ; Lajas, Guayama, Ponce, Sabana Grande (H. L. D.) ; Tres Hermanos, Mayaguez, Ensenada (M. R. S.)

This introduced species is very commonly distributed throughout many of the West Indian Islands and is perhaps much more widely distributed in Puerto Rico than the above records would indicate. Workers have been collected on a number of occasions from cow dung in pastures in the very dry areas of the Island, also on sandy beaches in the more moist areas. The ants are capable of nesting in the soil or in wood. The workers are thought to be highly predacious, although they attend honeydew-excreting insects to some extent.

The worker can be distinguished from that of the other members of the genus by its very small size, and by the short, distinctly clavate hairs on the thorax, the very short epinotal spines, and the feebler sculpturing of the body.

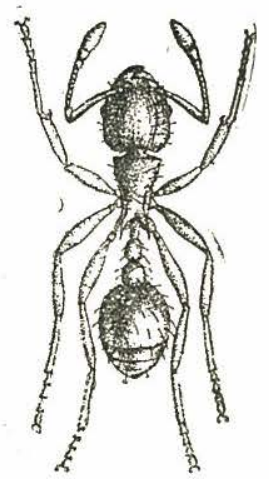

Fig. 11. Wasmannia auropunctata Roger (After Wheeler.) 


\section{Wasmannia auropunctata Roger.}

Berl. Ent. Zeitschr. Vol. 7, p. 182, 1863. All castes

Culebra (W. M. W.) ; Utuado, Monte Morales, Monte Mandios, Adjuntas, Coamo Springs, El Morro at San Juan, Vega Baja (W. M. W.) ; Ciales (Van Z.) ; Quebradillas (G. N. W.) ; Guánica (H. L. D.) ; Río Piedras (J. D. M.) ; 14 kilometers northeast of Ponce, Lajas, Lares, San Sebastian, Arecibo, Juana. Díaz (M. R. S.)

This ant, which is known as the "albayalde" by the natives, is one of the most common of all the Puerto Rican ants. It is also very generally distributed throughout the West Indies. The natives claim that the sting is dreaded by them even more than that of the "hormiga brava" because it is much more last-. ing. Also, owing to the small size of the workers, the ants can conceal themselves in one's clothing and not be so easily detected. Colonies are very populous and may be found either in the soil or in rotten $\log _{\mathrm{s}}$ and stumps. Although the "albayalde" is one of the most common ants in densely shaded areas such as coffee groves, it also occurs in open pastures, sandy beaches, etc., and lives in the very arid regions of the Island as well as in the more moist areas.

As an attendant on honeydew-excreting insects the ant is scarcely surpassed, unless it be by the "hormiga brava." Workers have been noted on numerous occasions attending the green and hemispherical scales; the mealybugs Pseudococcus brevipes, Ps. sacchari Ckll., and Ps. virgatus Ckll.; and the aphids Toxoptera aurantiae, Sipha flava, and Pentalonia nigronervosa. Their food probably consists of a great deal of flesh also. Van Zwaluwenberg is the authority A $\mathrm{Cr}$ the statement that this ant often kills out and displaces colonies of the "hormiguilla" Myrmelachista ramulorum Whir., in coffee groves. On March 18, male and queen pupae were found in a colony.

The small worker is recognized by its prominent antennal scrobe which not only extends to the posterior border of the head but is bordered laterally just above the eyes by a carina; the very prominent, angular, thoracic humeri; and by the elongate, acute, epinotal spines; as well as by its general light yellowish-brown color. 
42. Strumigenys eggersi Emery.

Bull. Soc. Ital., Vol. 22, p. 32, 1890. Worker, Queen.

Juana Díaz (J. W. Balock); Mayagüez, Maricao Insular Forest (M. R. S.)

S. eggersi does not seem to be as common a species in Puerto Rico as $S$. rogeri or $S$. louisianae var. obscuriventris. The species is also recorded from Cuba and the Island of St. Thomas.

A dealated queen was taken from the soil beneath a rock in the Maricao Insular Forest at an altitude of 3,000 feet. Balock found a colony comprising about 30 individuals in a pod beneath cow dung in a dry pasture area at Juana Diaz. A winged queen was noted in this nest on January 31 . The colonies of $S$. eggersi are very small, consisting of only a few dozen individuals. Absolutely nothing is known concerning the feeding habits of the ants. Kennedy, who made a study of the mouth parts of one species of Strumigenys in the United States, was led to infer that their food might be fungi.

The small worker (1.25-1.3 mm.) of this species is easily recognized by its elongate, slender, subparallei mandibles which have 6 to 7 minute denticles on their inner apical borders; and also by the very broad postpetiole, which is several times as broad as long.

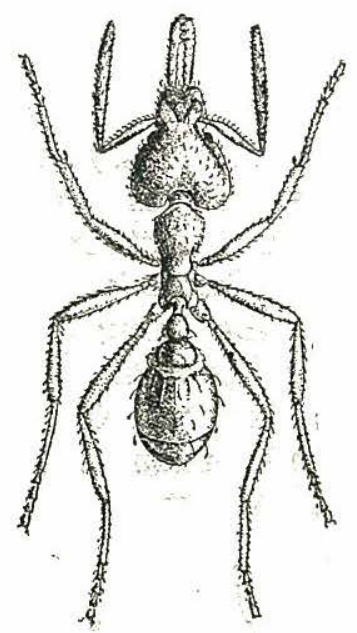

Fig. 12. Strumigenys rogeri Emery (After Wheeler.) 
43. Strumigenys rogeri Emery.

Berl. Ent. Zeitschr., Vol. 7, pp. 253-254, 1862. Worter Coamo Springs (W. M. W.) ; Arecibo, Mayagüez (M. R. S.)

This is apparently one of the most common species of Strumigenys in Puerto Rico and the other West Indian Islands.

Wheeler found this ant nesting in the soil under stones in a nearly dry stream bottom. I have collected the ants from colonies in a stump in a rather densely shaded coffee grove, from the soil at the base of a tree in a coffee grove, and from the soil beneath a stone near a small stream. What has been said about $S$. eggersi with regard to the size of colonies and possible food may also be applied to this species.

The worker of rogeri. which is $1.6 \mathrm{~mm}$. in length, can be distinguished from the workers of other members of this genus by its cordate, deeply emarginate head; elongate mandibles, with two prominent subapical teeth on the inner border of each mandible before the apical teeth, and by the erect infraspinal laminae on the epinotum of the thorax.

44. Strumigenys membranifera subsp. simillima Emery.

Bull. Soc. Entom. Ital., Vol. 22, p. 69, 1890. Worker

Lajas (H. L. D.)

A single specimen of this ant, a worker, was collected by Dozier from a clump of rather dry cow dung in a dry, arid pasture. The species has not been recorded from any of the other West Indian Islands except St. Thomas, from which it was originally described. Recently the species was recorded by me from Mississippi, this being the first time that it was noted in the United States. In Mississippi the species commonly nests in the soil beneath stones, wood, or debris. Colonies consist of only a few dozen individuals. Nothing is known about the food preferences of the ants.

The worker, which is $1.5 \mathrm{~mm}$. in length, is characterized by the peculiar shape of its head which is distinctly rectangular anteriorly, by the coarse punctate sculpturing of the head, the small, triangular shaped mandibles, etc. 


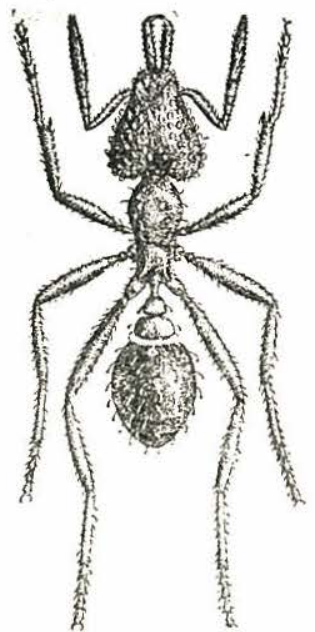

Fig. 13. Strumigenys louisianae obscuriventris Wheeler (After Wheeler.)

45. Strumigenys louisianae var. obscuriventris Whlr.

Bull. Amer. Mus. Nat. Hist., Vol. 24, p. 145, 1908 Worker Utuado, Coamo Springs (W. M. W.) ; Ensenada, Mayagüez (M. R. S.)

Colonies of this ant have been found nesting in the soil beneath stones. At Ensenada the ants were collected from a dry pasture in one of the most arid sections of the island. Isolated workers have also been collected from rather densely shaded moist areas. Undoubtedly the species is highly adaptable to conditions of varying moisture and temperature. What has been said about the biology of the preceding species will also apply to this variety.

Wheeler, who described the variety obscuriventris from Puerto Rican specimens, states that it differs from the typical species "in having the gaster, except at the base, dark brown or black, and the ferruginous tint of the body in general darker." The worker is recognized by its elongate mandibles, the inner preapical border of which has a single tooth just before the apical teeth, and by the very distinctly squamiform hairs of the head, as well as by its size $(2.25 \mathrm{~mm}$.) 
46. Epitritus emmae Emery

Bull. Soc. Ent. Ital., Vol. 22, p. 33, 1890. Worker

Arecibo, Ensenada (M. R. S.)

Originally described from St. Thomas, this species has not been recorded from any of the other West Indian Islands except Puerto Rico and Cuba.

On one occasion two workers of this species were found nesting in the soil beneath a stone in an open pasture in one of the most arid areas of the Island. At Arecibo a single specimen, a worker, was found in the soil beneath a clump of Bermuda grass at the edge of a pineapple field. The colonies are undoubtedly very small, like those of Strumigenys. Nothing is known of the food habits of this species.

The worker is characterized by its 4-segmenter antennae, the rectangular-shsped anterior section of its head, the squamiform hairs on the head, and its small size $(1.25 \mathrm{~mm}$.)

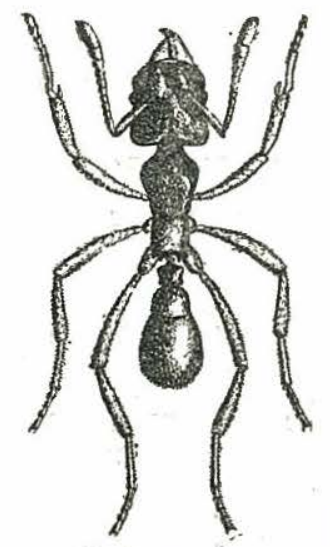

Fig. 14. Myrmicocrypta brittoni Wheeler. (After Wheeler.)

47. Myrmicocrypta brittoni Whlr.

Bull. Amer. Mus. Nat. Hist., Vol. 23, pp. 728-729, 1907. Worker.

Santurce (W. M. W.)

This species of fungus ant was described from specimens taken in Puerto Rico and has not yet been recorded from any of 
the other West Indian Islana's. I have not been fortunate enough to collect the species, hence know nothing concerning the nesting habits and biology of the ant.

The worker of this species, which is monomorphic, has the frontal carinae very close to each other and dilated at the anterior extremity, the clypeus not distinctly prolonged between them; and the integument bristling with tubercules and spines, with hooked and scale like hairs.

48. Cyphomyrmex rimosus subsp. minutus Mayr.

Verh. Zool. Bot. Ges. Wien., Vol. 12, p. 691, 1862. Worker

Culebra (W. M. W.) ; Arecibo, Adjuntas, Utuado, Monte Mandios, Monte Morales, Coamo Springs (W. M. W.) ; Hatillo, San German (H. L. D.) ; Rio Piedras, Cayey (G. N. W.) ; Ponce, Lajas, Mayaguez, Juana Díaz (M. R. S.)

This small fungus ant is not only a common species in Puerto Rico but it is abundantly distributed throughout many of the other West Indian Islands. I have found colonies of $m i$ nutus nesting in rotten stumps and $\log s$ and in the soil beneath stones. Apparently the species is adapted to living in both arid and moist regions of the island. The colonies are very small, comprising only a few dozen individuals. Dozier on a number of occasions has collected the workers from cow dung. The worker of this ant, because of its small size and resemblance in color to the soil, is not always easy to see, and furthermore the ants have the habit of feigning death. Their food consists of yellowish, pear-shaped bodies of fungus. They may also eat flesh.

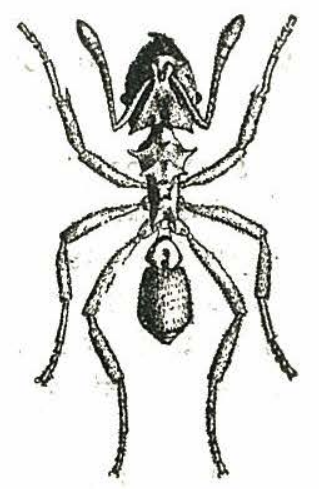

Fig. 15. Mycocepurus smithi Wheeler (After Wheeler.) 
Madden found workers which he thought were feeding on nymphs of the mole cricket, Scapteriscus vicinus.

The monomorphic worker is distinguished by its prominent antennal foveae, scale-like hairs of the body, well-separated frontal carinae, etc.

\section{Mycocepurus smithi var. borinquenensis Whlr.}

Bull. Amer. Mus. Nat. Hist., Vol. 23, p. 718, 1907. Worker

Vega Baja, Arecibo, Utuado, Monte Mandios, Coamo Springs (W. M. W.) ; Mayaguez, San Sebastian (M. R. S.)

This variety of fungus ant, which was described from Puerto Rican specimens, has not yet been recorded from any of the other West Indian Islands except Cuba. The colonies, which are very small, nest in the soil. The entrance hole to their nest is small and more or less obscured by the earth thrown over and around it. The workers superficially bear a resemblance in size, color, and opaqueness to those of certain species of Pheidole of the flavens group. The ants are not uncommon in the western end of the island and have especially been noted in red clay soil, but may occur in other types of earth.

The worker is characterized by having the frontal carinae close to each other and dilated anteriorly, the petiole with four teeth dorsally, the postpetiole with a deep impression dorsally, and the gaster bordered on each side by a carina.

\section{Trachymyrmex jamaicensis André.}

Rev. d'Entom., p. 149, 1893. Worker

Culebra (W. M. W.)

This fungus ant has also been recorded from Cuba and Haiti. I have not been fortunate enough to collect it in the main island. Mann, who studied the habits of this species in Haiti, states that the colonies are rather large. He found them nesting in the plain as well as in other localities which were more humid. In every case the nest was shaded. According to him the workers are diurnal but prefer the late afternoon for foraging. The food of these ants consists of a fungus which grows from a substratum made of leaves, buds, and other vegetable substarices. 


\section{KEY TO THE SPECIES OF THE FAMILY DOLICHODERINAE.}

(for the identification of workers)

1. Scale of petiole either vestigial or absent

Scale of petiole more or less inclined, but well developed

2. Antennal scapes surpassing the posterior border of the head; head and thorax dark, gaster light_...----

Tapinoma melanocephalum Fabr.

Antennal scapes not reaching the posterior border of the head _._._. Tapinoma littorale Whlr.

3. Epinotum with a sharp and pointed conical elevation Dorymyrmex pyramicus var. niger Perg. Epinotum without a conical elevation, but with a gibbous protuberance dorsally

4. Head and thorax honey-yellow Iridomyrmex melleus Whlr.

Head and thorax fuscous Iridomyrmex melleus var. fuscescens Whlr.

\section{SUBFAMILY DOLICHODERINAE}

\section{Tapinoma melanocephalum Fabr.}

Entom. System., Vol. 2, p. 353, 1793. Worker

Culebra (W. M. W.) ; Arecibo, Utuado, Ponce, Taliaboa (W. M. W.) ; Río Piedras (J. D. M.) ; Mayagüez, Guánica, Lajas, Tres Hermanos, Lares (M. R. S.)

This ant is not only common in Puerto Rico but is widely distributed throughout the Islands of the West Indies. It is quite versatile in its nesting habits, colonies occurring in the soil beneath stones, under the bark of trees, in hollow twigs, cavities, etc., of plants or trees, and also in rotten logs and stumps. Colonies are sometimes found nesting between the leaves of Tillandsias. Colonies appear to be moderately populous. There are many queens to a nest. The workers are highly predacious as well as lovers of honeydew. They have been noted attending the pineapple mealybug, the green scale, etc. The workers have given repeated trouble by invading insectaries and stealing the insects being reared therein. The ant is an inveterste house-attending form, sometimes even nesting in the house. The very small workers run along at a very rapid, erratic pace. When against a dark surface they give the appearance of a large mite. Workers have the peculiar "Tapinoma odor" characteristic of this group of ants. In Puerto Rico the 
ant is commonly known as the "albaricoque", and in Cuba as the "hormiga boticaria", both names of which apply to the pe. culiar odor of this insect.

The worker is distinguished from that of the other species of Tapinoma here mentioned by its long antennal scapes, which exceed the posterior margin of the head, and by its distinctive color, the head and thorax being dark brown and the gaster whitish.

52. Tapinoma littorale Whlr.

Bull. Amer. Mus. Nat. Hist., Vol. 21, p. 109, 1905. All castes.

Monte Morales, Monte Mandios (W. M. W.) ; Doña Juana (H. L. D.) ; Maricao, Maricao Insular Forest, 14 kilometers east of Mayagüez (M. R. S.)

This species is apparently not so common as the preceding one, having been recorded to date only from the Bahamas, Cuba, and Santo Domingo. Wheeler's name littorale has not proved very distinctive for this species in Puerto Rico as neither he nor I have been able to find it elsewhere than away from the beaches, usually on mountains or hillsides. In every instance so far, the colonies of this ant have been collected from plants or trees where they have been nesting in hollow twigs or stems, in crevices between leaves, etc., indicating that the species is mainly ifi not altogether arboreal. In Puerto Rico the species has been taken most commonly at high altitudes of 3,000 feet or more. Little is known of the food habits of the ants, but it is inferred that they are probably given largely to attending honeydew-excreting insects. Dozier found workers attending a flat, black scale (Lecanine) on a palm at an altitude of 3,000 feet. When running over plants outdoors the species is very apt to be mistaken for Brachymyrmex heeri, which it closely resembles in size and color.

The small size of the worker (1.25-1.5mm.), its short antennal scapes (not attaining the posterior border of the head), and its generally pale- yellow color, with occasionally an infuscation dorsally, serve to distinguish the worker of littorale from that of melanocephalum. 


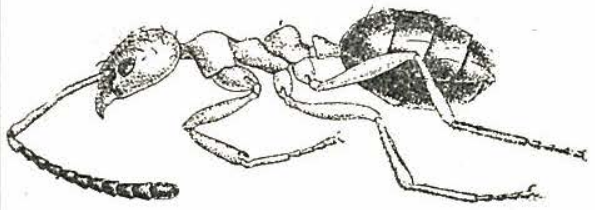

Fig. 16. Iridomyrmex melleus Wheeler. (After Wheeler.)

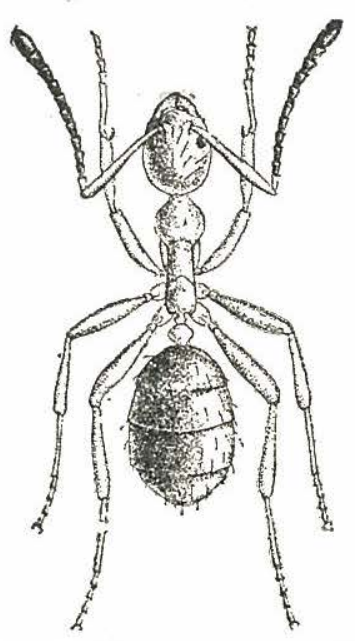

Fig. 17. Iridomyrmex melleus Wheeler. (After Wheeler.)

\section{Iridomyrmex melleus Whlr.}

Bull. Amer. Mus. Nat. Hist., Vol. 24, pp. 151-153, 1908. All Castes.

Arecibo, Utuado, Monte Morales, Monte Mandios, Coamo Springs, Vega Baja (W. M. W.) ; Guayama (J. D. M.) ; Corazal, Aibonito (G. N. W.) ; Yauco, Las Marías, Mayagüez, San Germán, Maricao Insular Forest (M. R. S.)

This species, which was described from Puerto Rican specimens, has not yet been collected from any of the other West Indian Islands. This ant is extremely common and is apparently almost entirely confined to the mountains and hills; generally the species is found nesting in hollow twigs of trees or in crevices under the bark, between the leaves of Tillandsias, in rotten logs or stumps, in cocoons of the moth Megalopyge krugtu Uैewrtz, aria sometımes constructing a carton-like material over its nest on leaves. On one occasion, which was a very exceptional one, a colony was found nesting in the soil beneath a stone. The colcnies are moderately populous. The workers are ardorear $\mathrm{mr}$ naw and given to attending honeydew-excreting insects. They have been noted attending a mealybug, Pseudococcus sp., on Tillandsias, the green and hemispherical scales on coffee, and the plant louse Toxoptera avrantiae. When 
alarmed the workers can run very rapidly. I have not beer able to detect any odor about the workers as with some of the other species of Iridomyrmex. Winged males and queen pupar were noted in a nest on August 1.

The worker, which is from 2.0 to $2.25 \mathrm{~mm}$. in length, is distinguished by its slender, graceful appearance; genera honey-yellow colored body, with infuscated gaster. All of the antennae, except the scape and first segment, are infuscated.

\section{Iridomyrmex melleus var. fuscescens Whlr.}

Bull. Amer. Mus. Nat. Hist., Vol. 24, p. 153. 1908. Worken

Monte Morales, Monte Mandios (W. M. W.); Maricac Insular Forest (M. R. S.)

In the Maricao Insular Forest I found this species very common at an altitude of approximately 3,000 foot where colonies were noted quite frequently back of where the axil of the leaf sheath attaches to the trunk of the Sierra Palm, Euterpe globosa Gaertn. Other colonies were found nesting under the same conditions as the species. Apparently the habits of the two forms are too similar to warrant further remarks.

The worker bears a striking superficial resembiance to that of the Argentine ant, Iridomyrmex humilis Mayr, in both size and color, and in its habit of rumning around very rapidly.

The worker of fuscescens is distinguished from that of melleus by its more fuscous body and appendages, with black gaster, yellowish mandibles, and whitish tarsi.

55. Dorymyrmex pyramicus var. niger Perg.

Proc. Cal. Acad. Sci., Vol. 5, p. 871, 1895. Worker

Santurce, Arecibo, Utuado, Adjuntas, Ponce, Aibonito, Coamo Springs, Vega Baja (W. M. W.) ; Boqueron (H. L. D.) ; San Germán, Tres Hermanos, Ensenada (M. R. S.)

This dark variety of the so-called "lion ant" has been recorded from the Bahamas, Cuba, Jamaica, Haiti, and Santo Domingo. Its nests are crater-shaped affairs constructed in rather open, sunny places. I have noted the ants in some of the driest areas of the island as well as in the more moist localities. Wheeler states that the ants nest in sandy areas, which 
is true, but the species also nests in clay soils. Colonies are not very populous, usually containing only a few hundred individuals. Workers feed on both flesh and honeydew. Workers have the peculiar "Tapinoma odor" characteristic of this ant and some of the other Dolichoderine ants.

The worker can be distinguished from othcr closely related forms by its very distinctive cone-shaped epinotum, its long maxillary palpi, and very dark color.

\section{KEY TO THE SPECIES OF THE SUBFAMILY FORMICINAE}

\section{(for the identification of the workers)}

1. Antennae with 9 segments

Antennae with more than 9 segments

2. Last segments of the antennae forming a differentiated club; arboreal species

Not as above

3. Length 1.75 to $2.3 \mathrm{~mm}$.; second funicular segment broader than long.-- Myrmelachista ramulorum

Whlr.

Length 2.3 to $2.6 \mathrm{~mm}$; larger and stouter; second funicular segment longer than broad. Myrmelachista ramulorum var. fortior Whlr.

4. General body color yellowish, or yellowish brown Brachymyrmex heeri Forel General body color brownish black _._. Brachymyrmex heeri var. obscurior Forel

5. Workers monomorphic

Workers polymorphic

6. Antennal scapes very greatly surpassing the posterior border of the head, apparently twice the length of the head or more; body slender and graceful Paratrechina longicornis Latr.

Characters not as above

7. Eyes extremely small, with apparently only 7 or 8 ommatidia; color pale yellowish brown__._.__Prenolepis

(Nylanderia) microps, sp. nov. Eyes much larger, with many more ommatidia; color darker

8. Mesopleurae opaque, due to the dense pubescence covering it_._._Prenolepis (Nylanderia) fulva Mayr. Mesopleurae smooth and shining-

9. Mesonotum with four macrochetae; all the body and appendages reddish brown, gaster darker Prenolepis (Nylanderia) steinheili Forel Not as above_Prenolepis (Nylanderia) vividula Mayr. 
is true, but the species also nests in clay soils. Colonies are not very populous, usually containing only a few hundred individuals. Workers feed on both flesh and honeydew. Workers have the peculiar "Tapinoma odor" characteristic of this ant and some of the other Dolichoderine ants.

The worker can be distinguished from othcr closely related forms by its very distinctive cone-shaped epinotum, its long maxillary palpi, and very dark color.

\section{KEY TO THE SPECIES OF THE SUBFAMILY FORMICINAE}

\section{(for the identification of the workers)}

1. Antennae with 9 segments

Antennae with more than 9 segments

2. Last segments of the antennae forming a differentiated club; arboreal species

Not as above

3. Length 1.75 to $2.3 \mathrm{~mm}$.; second funicular segment broader than long.-- Myrmelachista ramulorum

Whlr.

Length 2.3 to $2.6 \mathrm{~mm}$; larger and stouter; second funicular segment longer than broad. Myrmelachista ramulorum var. fortior Whlr.

4. General body color yellowish, or yellowish brown Brachymyrmex heeri Forel General body color brownish black _._. Brachymyrmex heeri var. obscurior Forel

5. Workers monomorphic

Workers polymorphic

6. Antennal scapes very greatly surpassing the posterior border of the head, apparently twice the length of the head or more; body slender and graceful Paratrechina longicornis Latr.

Characters not as above

7. Eyes extremely small, with apparently only 7 or 8 ommatidia; color pale yellowish brown__._.__Prenolepis

(Nylanderia) microps, sp. nov. Eyes much larger, with many more ommatidia; color darker

8. Mesopleurae opaque, due to the dense pubescence covering it_._._Prenolepis (Nylanderia) fulva Mayr. Mesopleurae smooth and shining-

9. Mesonotum with four macrochetae; all the body and appendages reddish brown, gaster darker Prenolepis (Nylanderia) steinheili Forel Not as above_Prenolepis (Nylanderia) vividula Mayr. 
10. Head of major worker light red anteriorly; with pale spots often on first and third as well the second gastric segment; minor worker usually with spots only on the second segment. Head, thorax, and gaster of both major and minor workers dark brown, smooth and shining-_Camponotus sexguttatus Fabr.

Color light yellowish brown, with the head and segments of the gaster often infuscated

Camponutus ustus Forel.

\section{SUBFAMILY FORMICINAE}

\section{Brachymyrmex heeri Forel} Worker.

Denkschr. Schweiz. Ges. Naturw., Vol. 26, p. 91, 1874.

Culebra (W. M. W.) ; Santurce, Utuado (W. M. W.) ; Maricao Insular Forest, Mayagüez, Lajas, Las Marías, Juana Díaz (M. R. S.)

This minute species appears to live by preference in such habitats as coffee and citrus groves or well-shaded woods, although the ants are sometimes noted in open areas. The very small colonies, comprising only a very few hundred individuals, are found in the soil beneath objects or also even in rotting logs and stumps. The workers are exceedingly fond of honeydew and have commonly been observed attending the green and hemispherical scales, mealybugs on guaba believed to be Pseudococcus virgatus Ckll., the pineapple mealybug, and the aphids Pentalonia nigronervosa and Aphis spiraecola Patch. I have seen them attending the hemispherical scale along with workers of Wasmannia auropunctata. Winged queens were noted in a colony on February 14.

The worker is easily distinguished by its small size, its 9segmented antennae, and its yellowish to yellowish-brown color.

57. Brachymyrmex heeri var. obscurior Forel

Trans. Ent. Soc. Lond., p. 345, 1895. All castes.

Santurce, San Juan (W. M. W.) ; Hatillo, San Germán (H. L. D.) ; Arecibo, Juana Díaz, Lajas, Ensenada, Mayagüez, Hormigueros, Tres Hermanos (M. R. S.)

This dark variety of $B$. heeri is not only a very common 
ant in Puerto Rico but it is widely distributed throughout the West Indies. The ants form rather small colonies in the soil or in rotting log:s and stumps, nesting by preference in more open areas than the preceding species. The ants if anything, apparently exceed $B$. heeri workers in their love for honeydew. They have been observed attending such economic insects as the green and hemispherical scales, and the aphids Sipha flava on sugar cane, Pentalonia nigronervosa on bananas and plantains, and Aphis spiraecola on citrus. As an attendant on the pineapple mealybug in Puerto Rico this ant is only excelled by the "hormiga brava". The workers must feed largely, if not almost exclusively, on honeydew. I have actually seen workers of this species with apparently uninjured and healthy pineapple mealybugs in their mouths.

The worker is recognized by its short, robust form, its 9segmented antennae, and its very dark brown color.

\section{Prenolepis (Nylanderia) fulva Mayr.}

Verh. Zool. Bot. Ges. Wien., Vol. 12, p. 698, 1862. Worker, Queen.

\section{S.) \\ Humacao (Van Z.) ; Isabella (L. C. F.) ; Arecibo (M. R.}

This species has been recorded from Cuba, Haiti, and Santo Domingo. Apparently the species prefers to nest in more open areas than in the woods or well-shaded spots. Workers are exceedingly fond of honeydew and have been noted attending the following important economic insects; Pseudococcus sacchari on sugar cane, Aphis gossypii on cotton, and the pineapple mealybug on pineapple. A worker was noted transporting a pineapple mealybug in its mouth at Arecibo. Other workers had greatly distended gasters, indicating that they had just fed on large quantities of honeydew. On the western end of the Island $P$. fulva does not appear to be as common or as widely distributed as some of the other species of Prenolepis. The ants are believed to nest principally in the soil in moderately small colonies. Workers when alarmed are able to run very fast.

The worker of this species is distinguished from those of other Prenolepis by its larger size, robust appearance, the deep brownish color and opaqueness of the body, as well as its very 
long and large pilosity. There are more macrochetae on the mesonotum than with the species steinheili and antillana.

\section{Prenolepis (Nylanderia) vividula Nyl.}

Acta. Soc. Fennica, Vol. 2, p. 900, 1846. All castes.

Culebra (W. M. W.) ; Monte Mandios, Monte Morales , Utuado (W. M. W.) ; Maricao (G. N. W.)

I have not aken any specimens of Prenolepis which I could definitely refer to this species. The variety antillana is very commonly distributed throughout the West Indies. One would expect to find the ants nesting in small colonies in the soil beneath objects and also in logs and stumps. Wolcott records the ants as nesting in the stem of a banana plant at Maricao.

Not having seen specimens which I am positive belong to this species, it is impossible for me to characterize it.

\section{Prenolepis (Nylanderia) sieinheili Forel}

Trans. Ent. Soc. London, p. 324, 1893. Worker

Adjuntas, Santurce (W. M. W.) ; Lajas, Mayagüez, Maricao Insular Forest (M. R. S.)

Specimens of what I believe to be this species were collected from a colony in rich, mucky soil beneath a stone at the top of the Maricao Insular Forest at an altitude of 3,000 feet. The ants form small colonies in the soil or in rotting wood such as logs and stumps. Workers very probably feed on flesh as well as on honeydew. This appears to be one of the most common species of Prenolepis in Puerto Rico. It is also recorded from many of the other West Indian Islands.

The worker is characterized by having four large macrochetae on its mesonotum and the rest of the body is reddishbrown except the gaster, which is a little darker.

61. Prenolepis (Nylanderia) microps sp. nov.

14 kilometers east of Mayagüez (M. R. S.)

Worker: Length, $2 \mathrm{~mm}$.

Head distinctly longer than broad, with very faintly emarginate border, and well-rounded sides and posterior angles. 
Mandibles with 6 distinct teeth, of which the apical, the fourth, and the basal teeth are the largest. Antennal scapes very long; exceeding the posterior border of the head by at least onethird their length; first funicular segment small, not very much longer than broad; all the other segments of the antennae very noticeably longer than broad. Eyes extremely small for a Prenolepis, oval, with 7 to 8 ommatidia. Thorax strongly depressed in the region of the meso-epinotal region where there is a pair of prominent spiracles. Base of epinotum rounded and apparently only one-third to one-fourth the length of the declivity. Petiole rather thick on its superior border, inclined forward. Legs long and slender.

Extremely smooth and shining, with dark, erect hairs rather abundant over all parts of the body, but especially on the head and gaster. The mesonotum with 8 large macrochaetae. Color pale yeliowish brown.

Described from 4 workers collected from the soil beneath a stone in a rather dense woods and not far from the edge of a stream. Cotypes in the collections of the United States National Museum and the writer.

The worker of this species differs from that of Mann's myops, to which i' is closely related, by the following characters: (1) Difference in the number of mandibular teeth (myops has four), and (2) the sides of the head are distinctly convex and not straight.

These ants appear to be strictly subterranean, as is indicated by their pale color, and extremely small eyes. Nothing is known of the ant's biology.

\section{Prenolepis (Nylanderia) longicornis Latr.}

Hist. Nat. Fourmis, p. 113, 1802. Worker

Culebra (W. M. W.) ; San Juan, Santurce, Arecibo, Utuado, Adjuntas, Ponce, Tallaboa, Coamo Springs (W. M. W.); Yauco, Caguas, Mameys (T. H. J.) ; Lajas, Ensenada, Mayagüez, Guánica, Tres Hermanos, Lares, Sabana Grande (M. R. S.)

This introdused ant is not only one of the most common ants in Puerto Rico but it is also widely distributed through 
the West Indies. From the towrs into which it was first imported the ants have rater been disseminated into the rural areas, until now the species is so abundant as to give one the impression that it is a native ant. This disiribution is not yet uniform even though one often encounters the ants in wooded areas and coffee groves considerably removed from habitations. The workers of this species are known by the native name of "hormiga loco" or ("crazy ant") because of the habit the workers have of often speeding around very swiftly helter skelter without any definite sense of direction. I have encountered the speies on the sandy beaches, in pastures in the driest areas of the island, as well as in moist and densely shaded areas. The workers are exceedingly fond of honeydew and have been observed on numerous occasions attending aphids, scales and mealybugs. They are known to attend the cotton aphid (Aphis gossypii), the green scale (Coccus viridis), the pineapple mealybug, (Pseudococcus brevipes), etc. This is one of the most important house-infesting ants in the island. Workers have been reported digging up lettuce seed and carrying tobacco seeds away from seed beds. Their fairly populous colonies may be found in the soil or in rotting wood.

The worker is easily recognized by its slender, graceful form, black color, and exceedingly long legs and antennae. The specific name, longicornis, well applies to the extremely long antennae of this species .

\section{Camponotus sexguttatus Fabr.}

Entom. Syst., Vol. 2, p. 354, 1793. Worker.

Culebra (W. M. W.) ; Fajardo, Morro at San Juan, Coamo Springs (W. M. W.) ; Loiza Aldea (H. K. P.) ; Mayagüez (J. S.) ; Coamo (G. N. W.) ; Naguabo (F. S.)

The genus Camponotus is very poorly represented in Puerto Rico. One of the largest and most beautiful species of this group in the island, rowever, is the species $C$. sexguttatus. It is apparently not sə common on the western end of the island as ustus. Wheeler states that "it lives either in hollow twigs of trees and bushes, in bark, or in nests of coarse, loose carton, which it builds around the stems of grasses in savannahs by agglutinating the thread-like particles of grass and other 
debris." The carton-like material is also used by the ants for plugging the open holes of twigs, or cavities in plants in the interior of which they nest. Plank found a colony nesting inside the dried fruits of the Frescora tree.

They were also collected by Sepulveda from the rotten roots of a mango tree in which they were nesting. Colonies are not thought to be very populous, probably consisting of only a few hundred individuals. Nothing is known of the ant's food habits. Owing to the variability of the spots in the color markings of these ants, they have been described many times under diverse names.

The characters mentioned in the key to the species will serve to distinguish sexguttatus from any other species with which it might be confused.

\section{Camponotus ustus Forel.}

Bull. Soc. Vaud. Sci. Nat. (2), Vol. 16, p. 75, 1879. All castes.

Culebra (W. M. W.) ; El Morro at San Juan, Utuado, Monte Morales (W. M. W.) ; San Sebastián, Ciales, Lares (G. N. W.) ; Mayagüez, Maricao Insular Forest, Ensenada (M. R. S.)

This species, which is rather common in Puerto Rico, has also been recorded from Haiti and the Virgin Islands.

Wheeler found the ants "nesting in the hollow twigs of the sea grape, Coccoloba uvifera." In Culebra he noted them nesting in the ground beneath a block of coral. Wolcott records C. ustus as being colonized in an old stump, and also in dead twigs of Inga vera.

On numerous occasions I have taken the species in the vicinity of Mayagüez, where they were found nesting in stumps, posts, dead branches of trees, etc., in colonies of only a few hundred individuals each. The smaller workers are very fast of foot and secretive. The soldiers can bite rather painfully when cornered.

At Ensenada a colony of the ants was found nesting in a dead branch of a tree in one of the driest and most arid areas of the island. When workers and soldiers were dropped on the 
hot ground in full exposure to the sun they ran around frantically'for several minutes and then expired. It is believed from this that the ants are crepuscular or night-working forms which do not forage during the daytime.

The amount of infuscation on the head as well as the general color of the body seems to be quite variable.

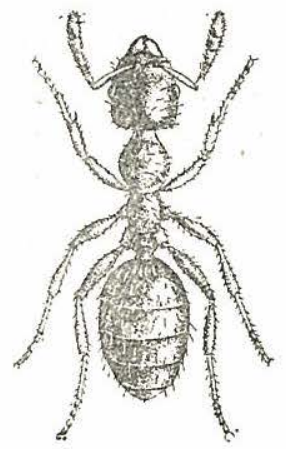

Fig. 18. Myrmelachista ramulorum Wheeler (After Wheeler.)

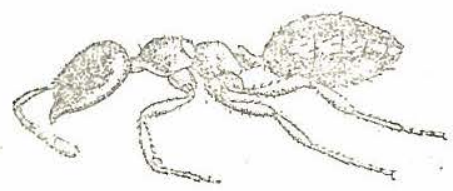

Fig. 19. Myrmelachista ramulorum Wheeler (After Wheeler.)

65. Myrmelachista ramulorum Whlr.

Bull. Amer. Mus. Nat. Hist., Voi 24, pp. 155-156, 1908. All castes.

Culebra (W. M. W.) ; Arecibo, Utuado (W. M. W.) ; Lares, Yauco, Cayey, and Ciales Valley south of Manati (G. N. W.) ; Mayagüez, 15 kilometers northeast of Yauco, San Sebastian, Maricao (M. R. S.)

This ant, which is known by the local name of the "hormiguilla", was described by Wheeler from Puerto Rican specimens. Since that time the species has been taken in Santo Domingo and the Virgin Islands. Wolcott states that he has observed the species nesting at sea level, and Tulloch has collected specimens from El Yunque at an altitude of 4,000 feet. The distribution of the ant is closely affiliated with that of the plantings of coffee, since the typical Puerto Rican coffee (Coffee arabica) is also dependent on much shade and perhaps a high degree of moisture, like the hormiguilla. The hormiguilla 
forms numerous colonies in the coffee shade trees, there being few trees that the ants do not nest in. Most of the individuals are to be found in the guama and guaba trees, one reason being that these are two of the most common kinds of shade trees in a coffee grove. un a moderate sized guaba tree I estimated there were 37,100 workers, 89 fertile or mother queens, and 60 winged males, or an average of 415 workers per queen. Since the ants nest inside of the twigs and galls of trees, one has little appreciation of the many, many thousands that may occur in a coffee grove. In one badly infested cuerda I estimated that there were over 5,000,000 ants. Inside of the galls and twigs of guama and guaba especially, and of a few other shade trees, the ants obtain much honeydew from the scale Cryptostigma inquilina Newstead, but this is also supplemented by honeydew obtained from such scales as Coccus viridis and Saissetia hemispherica, the plant louse Toxoptera aurantiae, and the mealybug Pseudococcus nipae and P. citri. In old, badly neglected coffee groves, especially where the guama and guaba trees are allowed to get very large, these ants migrate over into coffee and injure it by tunneling in the branches or trunk, by girdling the tree, or by causing large and unsightly galls. At picking time or during hurricanes the trees are badly injured through breakage resulting from the initial attack of these ants. Males have been seen at lights on nümerous occasions, but no winged queens. It is believed that the males fertilize the queens on or in trees without these winged forms having to take the ordinary nuptial flight. Only on one occasion were winged queens and queen pupae encountered in a nest and this on December 13 .

The worker is recognized by its 9 -segmented antennae, its dark head and gaster with yellowish-red thorax, and its yellowish appendages.

66. Myrmelachista ramulorum subsp. fortior Whlr.

Bull. Bus. Comp. Zool. Harvard, Vol. 77, pp. 189-190, 1934. Worker.

Mona Island (F. E. L.) ; Puerto Rico (W. M. W.)

This subspecies differs from specimens of the typieal ramulorum, according to Wheeler, in the following respects, 
"in being decidedly larger and more robust; the head larger and broader; joints two to five of the funieuli decidedly longer, the second distinctly longer than broad, the third and fourth as long as broad. Petiolar scale as in the typical form, with entire or very feebly and broadly sinuate superior border. In profile this border is decidedly thicke! and blunter; the posterior pedunculate extension of the petiole well-developed as in the typical form. Erect hairs on the body, scapes and tibiae even more numerous and longer. Coloration more vivid, the mandibles and head being deep red, the latter blackish behind, the thorax and appendages of a more reddish-yellow tint than in the typical ramulorum." Nothing is mentioned by Wheeler concerning the biology of this form.

In my studies of the hormiguilla in the coffee groves I have noted on frequent occasions considerable difference in the size of workers in various colonies, those in incipient or weak colonies being strikingly smali. This I attributed, however, to unfavorable conditions.

\section{BIBLIOGRAPHY}

Aguayo, C. G. New Ants of the Genus Macromischa. Pysche, 38; 175-183. 1931.

Notes on West Indian Ants. Bull. Bklyn. Ent. Soc., 27; 215-227. 1932.

Mann, W. M. Additions to the Ant Fauna of the West Indies and Central America. Amer. Mus. Nat. Hist. Bull., 42; 403-439. 1920.

Menozzi, C. Ants of Cuba and Canary Islands collected by Professor F. Silvestri. Bull. Lab. Zool. Gen. Agrar., 23; 1 - 5. 1929.

Contribution to the Knowledge of the Ant Fauna of the Dominican Republic. Bull. Lab. Zool. Gen. Agrar. Portici, 24; 148-173. 1930.

Santschi, F. Ants of Cuba and Panama. Rev. de Entom., 1; 265-282. 1931.

Wheeler, W. M. The Ants of the Bahamas (with a check list of the known West Indian Formicidae). Bull. Amer. Mus. Nat. Hist., 21: 79-135. 1905.

The Ants of the Bermudas. Bull. Amer. Mus. Nat. Hist., 22: 47-352. 1906.

The Ants of Jamaica. Bull. Amer. Mus. Nat. Hist., 24: 159-163. 1908 The Ants of Porto Rico and the Virgin Islands. Bull. Amer. Mus. Nat. Hist., 24: 117-158. 1908.

Additions to the Ant Fauna of Jamaica. Bull Amer. Mus. Nat. Hist., 30: 21-29. 1911.

Ants Collected in the West Indies. Bull. Amer. Mus. Nat. Hist., 2: 239-244. 1913. 

1913.

The Ants of Cuba. Bull Mus. Comp. Zool. Harvard, 54:477-505.

Jamaican Ants Collected by Professor C. T. Brues. Bull. Mus. Comp. Zool. Harvard, 61: 457-471. 1917.

Report on the Ants Collected by the Barbados-Antigua Expedition from the University of Iowa in 1918. Univ. of Iowa Stud. in Nat. Hist., 10: 3-9. 1923.

New and Little Known Ants of the Genera MACROMISCHA, CROESOMYRMEX and ANTILLAEMYRMEX. Bull. Mus. Comp. Zool. Harvard, 72: 1-34. 1931.

Wheeler, W. M. and Mann, W. M. The Ants of Haiti. Bull. Amer. Mus. Nat. Hist. 33; 1-61. 1914. 